\title{
Draft Nuremberg Speeches
}

Sir Hersch Lauterpacht, QC, FBA, LLD*

\section{Opening speech-Part I}

In pursuance of Article 6(a) of the Charter under which this Tribunal is constituted, ${ }^{1}$ the Second Count of the Indictment states as follows:

\begin{abstract}
All the defendants with diverse other persons, during a period of years preceding $8^{\text {th }}$ May, 1945, participated in the planning, preparation, initiation and waging of wars of aggression, which were also wars in violation of international treaties, agreements and assurances.
\end{abstract}

It is my duty as Representative and Chief of Counsel for the United Kingdom to present this part of the Indictment on behalf of the four States parties to the Agreement of 8 August, $1945^{2}$, setting up this Tribunal. The formidable and unprecedented catalogue of wars of aggression with the planning, preparation, initiation and waging of which the defendants are charged, is set forth in the Particulars of the Second Count of the Indictment. These wars were: ${ }^{3}$ against Poland, $1^{\text {st }}$ September, 1939; against the United Kingdom and France,

\footnotetext{
Sir Hersch Lauterpacht was Whewell Professor of International Law, University of Cambridge (1938-1955) and a Judge at the International Court of Justice (1955-1960). A line in the outer margin indicates that the text was used verbatim by Sir Hartley Shawcross in the final speech delivered at Nuremberg. Wherever possible, we have tried to preserve the original text and formatting used by Sir Hersch Lauterpacht. Footnotes refer the reader to the relevant pages of the final speech. The Cambridge Journal of International and Comparative Law is very grateful to Professor Sir Elihu Lauterpacht CBE QC LLD for his kind permission to publish the original draft, and to Bart Smit Duijzentkunst, Maria Fanou, Yin Harn Lee, Andrew Sanger and Rumiana Yotova for preparing the manuscript for publication.

11945 Charter of the International Military Tribunal, annexed to the 1945 Agreement for the Prosecution and Punishment of the Major War Criminals of the European Axis, 82 UNTS 280.

2 Ibid.

3 International Military Tribunal, Speeches of the Chief Prosecutors (His Majesty's Stationery Office, 1946), at 48.
} 
$3^{\text {rd }}$ September, 1939; against Denmark and Norway, $9^{\text {th }}$ April, 1940; against Belgium, the Netherlands and Luxembourg, $10^{\text {th }}$ May, 1940; against Yugoslavia and Greece, $6^{\text {th }}$ April, 1941; against the U.S.S.R., $22^{\text {nd }}$ June, 1941; and against the United States of America, $11^{\text {th }}$ December, 1941.

The long list of treaties, agreements, and assurances in violation of which these wars of aggression were undertaken is set forth in Appendix $C$ of the Indictment. They include the Hague Conventions relating to resort to pacific procedure prior to recourse to war, ${ }^{4}$, to the peace treaties between Germany and the Allied and Associated Powers and the United States of America, ${ }^{5}$ to the Locarno Agreement of October $1925,{ }^{6}$ to the express assurances given by Germany to countries which she invaded and subjugated in $1939,1940,1941^{7}$ and-primarily and above all-to that fundamental enactment of international society the General Treaty for the Renunciation of War. ${ }^{8}$

The task of the prosecution under this second Count of the Indictment falls into two parts: The first is to establish the fact of the violation of international undertakings, general or particular, in which Germany renounced any right which she may have possessed to resort to war. In this respect the task of the prosecution under Count II of the Indictment is, and has been, to a large extent covered by the presentation of Count I in so far as it refers to the gigantic, malevolent and ruthlessly executed conspiracy to bring about a war of aggression in violation of repeated and solemnly undertaken international obligations. For these breaches of international law were not isolated phenomena. They were not sporadic transgressions of a State driven to desperate means by unforeseen emergencies in defence of its very existence. They were the result of a preconceived long-range plan executed, with scientific precision, with a malice and a premeditation unparalleled in the annals of

${ }^{4} 1899$ Hague Convention for the Pacific Settlement of International Disputes, 187 CTS 410; 1907 Hague Convention for the Pacific Settlement of International Disputes (1907 Hague Convention No. I) 205 CTS 233; 1907 Hague Convention Relative to the Opening of Hostilities (1907 Hague Convention No. III), 205 CTS 263; 1907 Hague Convention Respecting the Rights and Duties of Neutral Powers and Persons in Case of War on Land (1907 Hague Convention No. V), 205 CTS 299.

51919 Treaty of Peace between the Allied and Associated Powers and Germany (Treaty of Versailles), 225 CTS 188.

61925 Treaty of Mutual Guarantee (Treaty of Locarno), 54 LNTS 289.

7 Appendix C lists assurances to Austria, the Netherlands, Belgium, Czechoslovakia, (including the 1938 Munich Agreement), Norway, Luxembourg, Denmark, Yugoslavia and the USSR (specifically the 1939 Treaty of Non-Aggression, also known as the Molotov-Ribbentrop Pact).

81928 General Treaty for Renunciation of War as an Instrument of National Policy (KelloggBriand Pact), 94 LNTS 57. 
history. That plan was unfolded in overwhelming detail in the presentation of the First Count of the Indictment by Counsel for the United States and by his associates. ${ }^{9}$ As the violations of these international undertakings are inseparable from the plan and the conspiracy to violate them, there must be some unavoidable overlapping in the elaboration of the first two Counts of the Indictment. That overlapping I will try to reduce to a minimum compatible with a coherent presentation of the charge. Some such slight degree of repetition, it is submitted, may not be altogether misplaced. It is imperative, accusing as we do before the bar of history, that the crime against the peace of the world - the crime of the greatest war which has brought civilization to the very brink of ruin-be proven up to the hilt. The question of "war guilt" must not be permitted to linger for decades in the realm of controversy or doubt. It must be settled by this Tribunal with authoritative finality. So persuasive and so overwhelming must be the impact of the evidence put before this Tribunal that enlightened public opinion and the conscience of the world will be able to brush aside, with quiet and righteous contempt, the objection that the verdict was given by a tribunal set up by and composed of the nationals of the victorious States. ${ }^{10}$ For these victorious States, whose cause has been identified with the survival of the law of nations, represent the vast majority of the inhabitants of the earth. It is not open to the defeated German nation, after it has defied, outraged, and brought upon itself the effective wrath of practically the entire civilized world, to make the legal and moral validity of any judgment passed upon it conditional upon its being pronounced by a neutral tribunal. There were, with insignificant exceptions, no neutrals left in a world which had risen to vindicate the violated rule of law and decency and to defend the very bases of its civilized existence. But because it is a Tribunal set up by the victorious nations, though acting in a very real sense on behalf of the enduring interests of the international community at large, we deem it our duty to present the evidence with an elaboration which history, far from considering an excessive or repetitive, will surely judge to be commensurate with dignity and with the necessities of this great occasion.

Our second task, though more general, we deem to be no less essential. The Charter has stigmatized the planning, preparation, initiation and waging of wars of aggression, which were also wars in violation of international

\footnotetext{
9 The US Chief Prosecutor was Robert H. Jackson, Associate Justice of the US Supreme Court.

${ }^{10}$ The judges of the International Military Tribunal were Sir Geoffrey Lawrence (President, UK), Sir Norman Birkett (Alternate, UK), Francis Biddle (US), John J. Parker (Alternate, US), Henri Donnedieu de Vabres (France), Robert Falco (Alternate, France), Iona Nikitchenko (USSR) and Alexander Volchkov (Alternate, USSR).
} 
treaties, agreements, and assurances, as being crimes against the peace, that is to say, as being international crimes coming within the jurisdiction of the Tribunal. The Charter has removed the initiation and execution of an aggressive war in violation of treaties from the category of a mere unlawful act under international law. It has placed them in the same category as ordinary war crimes and crimes against humanity. For the most obvious of reasons the Charter has put them first in the enumeration of crimes to be judged by the Tribunal. For the crime against the peace, the crime of war, was in the Second World war the parent and the occasion for the horrors of war crimes and of crimes against humanity. The term "crime against the peace" may create in some minds the impression of novelty. Moreover, inasmuch as the preparation and waging of war has been generally regarded as an action of the State, the Charter has deliberately adopted the notion that the State is capable of criminal conduct. Inasmuch as the Charter has expressly provided, in the second paragraph of Article 6, for individual responsibility for that crime, it has accepted a principle which, though not altogether alien to international law as hitherto practiced, is apt to be regarded as an innovation.

Now it would be entirely sufficient and proper for the prosecution to rely on the letter and the spirit of the express provisions of the Charter and to limit itself to showing that the wars into which Germany plunged mankind were wars of aggression and wars in violation of treaties, engagements and assurances. It is not incumbent upon the prosecution to prove that wars of aggression and wars in violation of treaties are or ought to be an international crime. The Charter has prescribed that this is so, and the Charter is the law of this Tribunal.

Yet, though this is the clear and mandatory law governing the jurisdiction of the Tribunal, we feel that the prosecution would not be fully acquitting itself of its task unless we made the effort, in the abiding interest alike of international justice and morality, to put in its proper perspective that apparent innovation of the Charter. The right of the belligerent to punish nationals of the enemy for transgressions against the laws and customs of war has been firmly established in international law for centuries. In this respect the Charter is declaratory of the law of nations. It embodies a significant concession in favour of the accused inasmuch as instead of facing a summary trial by a purely military court of one belligerent, they enjoy all the safeguards and all the indulgence of public judicial proceedings, almost literally within the hearing of the whole world, under the aegis of a high international tribunal of unimpeachable authority, learning and experience. Similarly, with regard to crimes against humanity, the community of nations has in the past claimed and successfully asserted the right to intercede on behalf of the violated rights of man trampled upon by 
the State in a manner calculated to shock the moral sense of mankind. The right of humanitarian intervention has for a long time been considered to form part of the law of nations. In this respect, too, the Charter merely develops a pre-existing principle. It provides not for repression but for punishment of crimes, including those committed by Germany in Germany against her own nationals, which have stirred and sickened the conscience of mankind to the point of doubting the human nature of the perpetrators of these horrors unknown in the annals of individual or collective crime. ${ }^{11}$

However, with regard to crimes against peace-the crime of war-covered by the second Count of the Indictment, we feel it incumbent upon the prosecution to comment, with some degree of elaboration if necessary, upon the provision of the Charter which is the foundation of this part of the Indictment. It is with regard to this aspect of the Charter that the public opinion of the world and, possibly, the judgment of history may, unless enlightened by the prosecuting nations responsible for this Indictment and the judgment of this Tribunal, be warped by plausible catchwords and by a distorted and uniformed refinement of a sentiment of justice towards these defendants. It is easy to fall a prey to such phrases as that resort to war in the past by sovereign States has never been a crime; that is has been of the essence of the prerogatives of sovereignty; that the Charter in retroactively constituting wars of aggression a crime has imitated one of the most obnoxious doctrines of National-Socialist jurisprudence, namely, post factum legislation; that the Charter is in this respect reminiscent of bills of attainder; and that it is no more than a measure of vengeance, subtly concealed in the garb of judicial proceedings, which the victor wreaks upon the vanquished. ${ }^{12}$ It would be easy for the prosecution to ignore these objections. It would be entirely within its legal right in insisting that the Charter is the law of the Tribunal and that it is in no need of any sort of apologia. But it would be contrary to the fitness of things for us to confine our purpose within such a narrow compass. Neither is it our wish to deny that some of the aspects-though not the principal aspect-of this part of the Charter are of significant novelty. But it is our view of the law and our conviction-which we affirm before this high Tribunal and before the opinion of the world-that, in essence, the provision of the Charter which constitutes wars of aggression an international crime is not in any way an innovation. It provides a competent jurisdiction for the punishment of what not only the enlightened conscience of mankind but also international law as enlarged and developed in the period

\footnotetext{
${ }^{11}$ Speeches of the Chief Prosecutors, supra note 3, at 48.

12 Ibid., at 49.
} 
between the two World Wars regarded as a crime for many years before the Charter of 8 August, 1945, constituting this Tribunal became part of the public law of the world. ${ }^{13}$

The terms "aggression" and "war of aggression" are not an invention of the Charter. They have figured prominently in numerous treaties, in governmental pronouncements and in declarations of statesmen in the period preceding the Second World War. In treaties concluded between the Union of Soviet Socialist Republics and other States-such as Persia (1 October, 1927) ${ }^{14}$, France (2 May, 1935) ${ }^{15}$, China (21 August, 1937) ${ }^{16}$-the Contracting Parties undertook to refrain from any act of aggression whatsoever against the other Party. In 1933 the Soviet Union became a party to a large number of treaties containing a detailed definition of aggression. ${ }^{17}$ The same definition appeared in the same year in the authoritative Report of the Committee on Questions of Security set up in connection with the Conference for the Reduction and the Limitation of Armaments. ${ }^{18}$ But States went beyond commitments to refrain from wars of aggression and to assist States victims of aggression. They condemned wars of aggression. Thus in the Anti-War Treaty of Non-Aggression and Conciliation of 10 October, 1933, a number of American States-subsequently joined by practically all the States of the American Continent and a number of European countries - the Contracting Parties solemnly declared that "they condemn wars of aggression in their mutual relations or in those of other States" ${ }^{19}$ That Treaty was fully incorporated into the Buenos Aires Convention of December 1936 signed and ratified by a large number of American countries,

\footnotetext{
${ }^{13}$ Ibid.

${ }^{14} 1927$ Treaty of Guarantee and Neutrality between Persia and the Union of Soviet Socialist Republics, 112 LNTS 275.

${ }^{15} 1935$ Treaty of Mutual Assistance between France and the Union of Soviet Socialist Republics, 167 LNTS 389.

${ }^{16} 1937$ Treaty of Non-Aggression between the Republic of China and the Union of Soviet Socialist Republics, 181 LNTS 101.

${ }^{17}$ See the 1933 Convention for the Definition of Aggression between Afghanistan, Estonia, Latvia, Persia, Roumania, the Union of Soviet Socialist Republics and Turkey, 147 LNTS 67; 1933 Convention for the Definition of Aggression between Roumania, the Union of Soviet Socialist Republics, Czechoslovakia, Turkey and Yugoslavia, 148 LNTS 211; Convention for the Definition of Aggression between Lithuania and the Union of Soviet Socialist Republics, 148 LNTS 79.

${ }^{18}$ Report of the Committee on Questions of Security (Politis Report), 24 May 1933, League of Nations Doc. Conf. D/C.G.108.

${ }^{19} 1933$ Anti-War Treaty of Non-Aggression and Conciliation between the Argentine Republic, Brazil, Chile, Mexico, Paraguay and Uruguay (Saavedra Lamas Pact), 163 LNTS 393.
} 
including the United States of America. ${ }^{20}$ Previously, in February 1928, the Sixth Pan-American Conference adopted a Resolution declaring that as "war of aggression constitutes a crime against the human species ... all aggression is illicit and as such is declared prohibited." In September 1927 the Assembly of the League of Nations adopted a resolution affirming the conviction that "a war of aggression can never serve as a means of settling international disputes and is, in consequence, an international crime" and declaring that "all wars of aggression are, and shall always be, prohibited."21 The first Article of the Draft Treaty for Mutual Assistance of 1923 read: "The High Contracting Parties, affirming that aggressive war is an international crime, undertake the solemn engagement not to make themselves guilty of this crime against any other nation." 22 In the Preamble to the Geneva Protocol of 1924 it was stated that "offensive warfare constitutes an infraction of solidarity and an international crime."23 These instruments remained unratified, for various reasons, but they are not without significance or instruction. ${ }^{24}$

These repeated condemnations of wars of aggression testified to the fact that, with the establishment of the League of Nations and with the legal developments which followed it, the place of war in international law had undergone a profound change. War was ceasing to be the unrestricted prerogative of sovereign States. The Covenant of the League ${ }^{25}$ did not totally abolish the right of war. It left certain gaps which probably were larger in theory than in practice. In effect it surrounded the right of war by procedural and substantive checks and delays which, if the Covenant had been observed, would have amounted to an elimination of war not only between Members of the League, but also, by virtue of certain provisions of the Covenant, in the relations of non-Members. Thus the Covenant restored the position as it existed at the dawn of international law, at the time when Grotius was laying the foundations of the modern law of nations and established the distinction, accompanied by profound legal consequences in the sphere of neutrality, between just and unjust wars.

\footnotetext{
${ }^{20} 1936$ Convention for the Maintenance, Preservation and Re-establishment of Peace, 188 LNTS 9.

${ }^{21}$ League of Nations Assembly, Declaration concerning Wars of Aggression, 24 September 1927.

${ }^{22}$ Draft Treaty of Mutual Assistance, League of Nations Doc. A.35 (1923) IX.

${ }^{23} 1924$ Geneva Protocol on the Pacific Settlement of International Disputes, 19 AJIL Supp. (1925), at 9.

${ }^{24}$ Speeches of the Chief Prosecutors, supra note 3 , at 51.

${ }^{25} 1919$ Covenant of the League of Nations, 225 CTS 195, at 128.
} 
Neither was that development arrested with the adoption of the Covenant. The right of war was further circumscribed by a series of treaties-numbering nearly one thousand-of arbitration and conciliation embracing practically all the nations of the world. The so-called Optional Clause of Article 36 of the Statute of the Permanent Court of International Justice ${ }^{26}$ which conferred upon the Court compulsory jurisdiction with regard to most comprehensive categories of disputes and which constituted in effect the most important compulsory treaty of arbitration in the post-war period, was widely signed and ratified. Germany herself signed it in 1927; her signature was renewed in 1933 and renewed, for a period of five years, by the National-Socialist Government in July 1933. (Significantly, that ratification was not renewed on the expiration of its validity in March 1938.) Since 1928 a considerable number of States signed and ratified the General Act for the Pacific Settlement of International Disputes $^{27}$ which was designed to fill the gaps left by the Optional Clause and the existing treaties of arbitration and conciliation.

All this vast network of instruments of pacific settlement testified to the growing conviction that war was ceasing to be the normal and legitimate means of settling international disputes. The express condemnation of wars of aggression, which has already been mentioned, supplied the same testimony. But there was more direct evidence pointing in that direction. The Treaty of Locarno of 16 October, 1925, to which I will refer later on and to which Germany was a party, was more than a treaty of arbitration and conciliation in which the parties undertook definite obligations with regard to the pacific settlement of disputes that may arise between them. It was, subject to clearly specified exceptions of self-defence in certain contingencies, a more general undertaking in which the parties agreed that "they will in no case attack or invade each other or resort to war against each other". This constituted a general renunciation of war and was so considered to be in the eyes of jurists and of the public opinion of the world. For the Locarno Treaty was not just one of the great number of arbitration treaties concluded at that time. It was regarded as the corner stone of the European settlement and of the new legal order in Europe in partial, voluntary and generous substitution for the just rigours of the Treaty of Versailles. With it the term "outlawry of war" left the province of mere pacifist propaganda. It became current in the writings on international law and in official pronouncements of governments. No jurist of authority and no statesman of responsibility would have associated himself, subsequent to the

\footnotetext{
${ }^{26} 1920$ Statute for the Permanent Court of International Justice, 6 LNTS 389.

${ }^{27} 1928$ General Act for the Pacific Settlement of International Disputes, 93 LNTS 343.
} 
Locarno Treaty, with the plausible assertion that, at least as between the parties, war had remained an unrestricted right of sovereign States.

But although the effect of the Locarno Treaty was limited to the parties to it, it had a wider influence in paving the way towards that most fundamental and truly revolutionary enactment in modern international law, namely, ${ }^{28}$ the General Treaty for the Renunciation of War of 27 August, 1928, known also as the Pact of Paris, or the Kellogg-Briand Pact, or the Kellogg Pact. That Treaty-a most deliberate and carefully prepared piece of international legislation-was binding in 1939 upon more than sixty nations, including Germany. Next to the International Postal Convention, ${ }^{29}$ it was-and has remained-the most widely signed and ratified international instrument. It contained no provision for its termination, and was conceived as the corner-stone of any future international order worthy of that name. It is fully part of international law as it stands to-day, and has in no way been modified or replaced by the Charter of the United Nations. ${ }^{30}$ It is indicated, in this solemn hour in the history of the world when the responsible leaders of a State stand accused of a premeditated breach of this great Treaty which was-and remains-a source of hope and faith for mankind, to set out in detail its two operative Articles and its Preamble.

The Preamble

The President of the German Reich, ......

Deeply sensible of their solemn duty to promote the welfare of mankind;

Persuaded that the time has come when a frank renunciation of war as an instrument of national policy should be made to the end that the peaceful and friendly relations now existing between their peoples may be perpetuated;

Convinced that all changes in their relations with one another should be sought only by pacific means and be the result of a peaceful and orderly progress, and that any signatory Power which shall hereafter seek to promote its national interests by resort to war should be denied the benefits furnished by this Treaty;

\footnotetext{
${ }^{28}$ Speeches of the Chief Prosecutors, supra note 3, at 52.

${ }^{29} 1874$ Treaty Concerning the Formation of a General Postal Union (Treaty of Bern), 19 Stat. 577. In 1878 , the treaty was amended to give the organization its current name, the Universal Postal Union.

${ }^{30} 1945$ Charter of the United Nations, 1 UNTS XVI.
} 
Hopeful that, encouraged by their example, all the other nations of the world will join in this humane endeavor and by adhering to the present Treaty as soon as it comes into force bring their peoples within the scope of its beneficent provisions, thus uniting the civilized nations of the world in a common renunciation of war as an instrument of their national policy;......

Article I

The High Contracting Parties solemnly declare in the names of their respective peoples that they condemn recourse to war for the solution of international controversies, and renounce it as an instrument of national policy in their relations with one another.

Article II

The High Contracting Parties agree that the settlement or solution of all disputes or conflicts of whatever nature or of whatever origin they may be, which may arise among them, shall never be sought except by pacific means.

In that General Treaty for the Renunciation of War practically the entire civilized world abolished war as a legally permissible means of enforcing the law and of changing it. Prior to that Treaty the right of war was of the essence of sovereignty. ${ }^{31}$ International law permitted resort to war not only for redressing an injury, but for challenging and destroying legitimate rights of other States. That right of war, so widely conceived, was, in the eyes of many, destructive of the claim of international society to be a community under the law. The victorious States at the end of the First World War, representing as they did almost the whole civilized world whose law Germany had defied and outraged, refused to recognize it. In Article 231 of the Treaty of Versailles they affirmed, and Germany accepted

the responsibility of Germany and her allies for causing all the loss and damage to which the Allied and Associated Governments and their nationals have been subjected as a consequence of the war imposed upon them by the aggression of Germany and her allies.

In Article 227 of the Treaty of Versailles they publicly arraigned "William II of Hohenzollern, formerly German Emperor, for a supreme offence against

\footnotetext{
${ }^{31}$ Speeches of the Chief Prosecutors, supra note 3, at 53.
} 
international morality and the sanctity of treaties". This they did although the Commission on Responsibilities set up by the Peace Conference considered that even "a war of aggression may not be considered as an act directly contrary to positive law" and although it recommended that "the acts which brought about the war should not be charged against their authors or made the subject of proceedings before a tribunal." It is probable that that was the law in 1918-although the Allied and Associated Powers by a supreme act of international legislation and by way of solemn warning to any future aggressor went beyond the law as it stood at that time. But is it conceivable that in 1939 or in 1945 any committee of jurists, with the Pact of Paris on the international statute book, would hold that a war of aggression is not contrary to positive law? That international enactment, which effected a change so fundamental in the law of nations, was repeatedly broken by the Axis Powers: by Japan in 1931, by Italy in 1935, by Germany in 1938, and by all three of them in 1939, 1940 and 1941. These breaches did not affect its validity. In a very true sense, except to the cynic and the malevolent, they added to its vitality. They provoked the sustained wrath of peoples angered by the contemptuous disregard of that great statute which was to make possible for the anguished world to rest securely under the shelter of the law.

It was not, I may add, a clumsy enactment likely to become a signpost for the guilty. It did not enable Germany to go to war against Poland and yet rely, as against Great Britain and France, on any immunity from warlike action because of the provisions of the Pact of Paris. For that Pact laid down expressly in its Preamble that no State guilty of a violation of its provisions may invoke its benefits. When on the outbreak of the Second World War Great Britain and France communicated to the League of Nations the fact that a state of war existed between them and Germany as from 3 September, 1939, they declared that by committing an act of aggression against Poland Germany had violated her obligations assumed not only towards Poland but also towards the other signatories of the Pact of Paris. A violation of the Pact in relation to one signatory was an attack upon all other signatories and they were fully entitled to treat it as such. It may be useful to refer to this point expressly in case any of the defendants should seize upon the letter of the Particulars of Count Two of the Indictment and maintain that it was not Germany who initiated war with the United Kingdom and France on 3 September, 1939. The declaration of war came from the United Kingdom and France; the act of war and its commencement came from Germany in violation of the fundamental enactment to which she 
was a party. ${ }^{32}$

The General Treaty for the Renunciation of War, that great constitutional instrument of international society awakened to the deadly dangers of another Armageddon, did not remain an isolated effort soon to be forgotten in the turmoil of recurrent international crises. It became, in conjunction with the Covenant of the League of Nations or independently of it, the starting point for a new orientation of governments in matters of peace, war and neutrality. It is of importance to quote some of these statements and declarations. In 1929, His Majesty's Government in the United Kingdom said in connection with the question of conferring upon the Permanent Court of International Justice jurisdiction with regard to the exercise of belligerent rights in relation to neutral States:

... But the whole situation ... rests, and international law on the subject has been entirely built up, on the assumption that there is nothing illegitimate in the use of war as an instrument of national policy, and, as a necessary corollary, that the position and rights of neutrals are entirely independent of the circumstances of any war which may be in progress. Before the acceptance of the Covenant, the basis of the law of neutrality was that the rights and obligations of neutrals were identical as regards both belligerents, and were entirely independent of the rights and wrongs of the dispute which had led to the war, or the respective position of the belligerents at the bar of world opinion.

... Now it is precisely this assumption which is no longer valid as regards states which are members of the league of nations and parties to the Peace Pact. The effect of those instruments, taken together, is to deprive nations of the right to employ war as an instrument of national policy, and to forbid the states which have signed them to give aid or comfort to an offender. As between such states, there has been in consequence a fundamental change in the whole question of belligerent and neutral rights. The whole policy of His Majesty's present government (and, it would appear, of any alternative government) is based upon a determination to comply with their obligations under the Covenant of the League and the Peace Pact. This being so, the situation which we have to envisage in the event of the war in which we were engaged is not

\footnotetext{
${ }^{32}$ Ibid., at 54.
} 
one in which the rights and duties of belligerents and neutrals will depend upon the old rules of war and neutrality, but one in which the position of the members of the League will be determined by the Covenant and the Pact .... (Memorandum on the Signature of His Majesty's Government in the United Kingdom of the Optional Clause of the Statute, Misc. No. 12 (1929), Cmd. 3452, p. 9).

Chief of Counsel for the United States referred in his opening speech before this Tribunal to the weighty pronouncement of Mr. Stimson, the Secretary of State, in which, in 1932, he gave expression to the drastic change brought about in international law by the Pact of Paris. It is convenient to quote the relevant passage in full:

War between nations was renounced by the signatories of the Briand-Kellogg Treaty. This means that it has become illegal throughout practically the entire world. It is no longer to be the source and subject of rights. It is no longer to be the principle around which the duties, the conduct, and the rights of nations revolve. It is an illegal thing. Hereafter when two nations engage in armed conflict either one or both of them must be wrongdoers-violators of this general treaty law. We no longer draw a circle about them and treat them with the punctilios of the duelist's code. Instead we denounce them as law-breakers.

Nearly ten years later, when numerous independent States lay prostrate, shattered or menaced in their very existence before the impact of the war machine of the Nazi State, the Attorney-General of the United States-subsequently a distinguished member of the highest tribunal of that great country-gave weighty expression to the change which had been effected in the law as the result of the General Treaty for the Renunciation of War. He (Mr. Robert H. Jackson, Attorney-General of the United States) said on 27 March, 1941:

... The Kellogg-Briand Pact of 1928, in which Germany, Italy, and Japan covenanted with us, as well as with other nations, to renounce war as an instrument of policy, made definite the outlawry of war and of necessity altered the dependent concept of neutral obligations. ${ }^{33}$

${ }^{33}$ Ibid., at 55 . 
... The Treaty for the Renunciation of War and the Argentine Anti-War Treaty deprived their signatories of the right of war as an instrument of national policy or aggression and rendered unlawful wars undertaken in violation of their provisions. In consequence, these treaties destroyed the historical and juridical foundations of the doctrine of neutrality conceived as an attitude of absolute impartiality in relation to aggressive wars. ...

It follows that the state which has gone to war in violation of its obligations acquires no right to equality of treatment from other states, unless treaty obligations require different handling of affairs. It derives no rights from its illegality.

... In flagrant cases of aggression where the facts speak so unambiguously that world opinion takes what may be the equivalent of judicial notice, we may not stymie international law and allow these great treaties to become dead letters. Intelligent public opinion of the world which is not afraid to be vocal and the action of the American states has made a determination that the Axis Powers are the aggressors in the wars today which is an appropriate basis in the present state of international organization for our policy....

There is thus no doubt that by the time the National-Socialist State had embarked upon the preparation of the war of aggression against the civilized world and by the time it had accomplished that design, aggressive war had, in virtue of the Pact of Paris and of other treaties, become illegal beyond all uncertainty and doubt. It is on that universal Treaty that Count Two of the Indictment is principally based. ${ }^{34}$ That Count refers indeed, in Appendix $\mathrm{C}$, to a long series of other international conventions violated by Germany such as the Hague Conventions of 1899 and 1907 for the Pacific Settlement of International Disputes, Hague Convention No. III of 1907 relative to the Opening of Hostilities, and Hague Convention No. V respecting the Rights and Duties of Neutral Powers and Persons in Case of War on Land. These Conventions have been included for the sake of completeness rather than with the intention to make them the subject matter of detailed argument before the Tribunal. Their substantive obligations, such as they are, are not in the same category as the solemn, rigid, and unequivocal obligation of the General Treaty for Renunciation of War. The Tribunal may not desire to see this trial prolonged by a detailed discussion of these instruments. Neither, especially with regard to

\footnotetext{
${ }^{34} \mathrm{Ibid}$., at 56.
} 
Hague Convention No. V (item 4 of Appendix C) do we wish to allow ourselves to be entangled in the meshes of the controversy bearing on the operation of the so-called general participation clause. We are content to submit that all these particular undertakings were merged in and rendered absolute by that great instrument of 1928 which prohibited and condemned all wars waged as an instrument of national policy.

The Prosecution has deemed it necessary-indeed imperative-to establish beyond all possibility of doubt, at what may appear to be excessive length, that only superficial learning or culpable sentimentality can assert that there is a decisive element of retroactive operation of the law in the determination of the authors of the Charter to treat aggressive war as conduct which international law has prohibited and stigmatized as criminal. We have traced the progressive limitation of the right of war, the renunciation and condemnation of wars of aggression, and, above all, the total prohibition and condemnation of all war conceived as an instrument of national policy. What statesman or politician in charge of the affairs of a nation could doubt, from 1928 onwards, that aggressive war, that all war-except in self-defence, or for the collective enforcement of the law, or against a State which has itself violated that Pact of Paris-was unlawful and outlawed? What statesman or politician embarking upon such war could reasonably and justifiably count upon an immunity other than that afforded by a successful outcome of the criminal venture? What more decisive evidence of a prohibition laid down by positive international law could any lawyer desire, than that which has been adduced here ${ }^{35}$ But the National-Socialist State had little use for international law. It relegated it to what it called "external State law". At the outset it paid lip-service to it for the transparent reason that Germany, at that time still complaining of the restrictions of the Treaty of Versailles, claimed with shrill insistence that equality of States is the principal tenet of international law. When equality was achieved, German lawyers prostituted international law as an ideology of "Grossraumsordnung"-the order of large spaces-under the hegemony of the master race. And they ended by defining it as "an intercorporative law of co-ordination based on racial co-sanguinity".

Yet, it may be argued-as it will probably be argued on behalf of the accused-that although war has been outlawed and forbidden, it has not been criminally outlawed and criminally prohibited. They will maintain that although international law has now made aggressive war an unlawful act, it has not made it a crime. They will assert that only an express international

\section{${ }^{35}$ Ibid.}


enactment could make an unlawful war a crime, and this for two reasons: The first, they will urge, is that international law, as we know it, does not attribute criminality to States; a State cannot commit a crime. The second argument on which they will rely is that international law is a law between States only and exclusively and that individuals acting on their behalf cannot be guilty of criminal acts under international law. They will claim, once more, that in so far as the Charter has introduced the principle of criminal responsibility of the State and of the individuals acting on its behalf, it is retroactive and contrary to a general principle of jurisprudence which they, in their day of power, treated with ridicule and contempt. The Charter is the law of this Tribunal. It would be open to the Prosecution to leave matters at that. But this is not a course which we propose to adopt at this historic trial. These are matters of the very highest moment for international morality, for the future peace of the world, and the authority of the law of nations on which that peace ultimately depends, and we propose to go into them, in due course, with an earnestness which we will do our best to make approximate to the magnitude of the occasion. In the meantime we must turn to the main object of this presentation of Count Two of the Indictment which is to put before the Tribunal the charge and the evidence of Crimes against Peace-crimes of which all the defendants stand accused. ${ }^{36}$

\section{Opening Speech-Part III}

This, then, is the evidence substantiating the charge, under Count Two of the Indictment, of planning, preparation, initiation and waging of wars of aggression, which were also wars in violation of international treaties, agreements and assurances. It is by reference to these acts that the defendants-all the defendants - stand accused of an international crime, of crimes against peace. I devoted the opening part of this statement to showing that the Charter has not, in this respect, introduced into the realm of international law a new offence with retroactive effect. It has provided an appropriate jurisdiction to judge the authors of a long series of aggressive wars. Will it be said on behalf of the defendants that States, including their own, have merely renounced war, that they have merely made it unlawful, that they have merely condemned it-but that they have not rendered it criminal? Will it be said by or on behalf of the defendants that the offence of these aggressive wars, which plunged millions of combatants to their death, which, by dint of war crimes and crimes against humanity, brought about the torture, starvation and extermination of millions of

\footnotetext{
${ }^{36}$ Ibid., at 57.
} 
civilians, which has devastated cities, which has destroyed the amenities-nay, the most rudimentary necessities - of civilization in many countries, which has brought the world to the brink of economic ruin from which it will take it generations to recover-will it be earnestly urged that such a war, that any war, is only an offence, only an illegality, only a subject of condemnation, but not a crime? Will the defendants say that breaches of treaties prohibiting war are in the same category as a breach of a convention providing for the most-favourednation clause or for the exchange of postal parcels or for the repayment of a debt?

Will it be seriously maintained on behalf of the defendants that in making aggressive war a crime the authors of the Charter have resorted to retroactive legislation and have imposed upon the Tribunal the invidious duty of applying it? No law worthy of that name can permit itself to be reduced to an absurdity. Certainly the Powers responsible for the Charter have refused to allow it. ${ }^{37}$ They drew the inescapable consequences from the renunciation, prohibition, and condemnation of war-all of which have become part of the positive law of nations. They refused to reduce justice to impotence by subscribing to the twin doctrines that the sovereign State cannot commit a crime and that neither can a crime be committed by those acting on its behalf. Their refusal to do so has decisively shaped the law of the Tribunal.

But we do not wish to stop at that. We submit that in so far as, in this respect, the Charter implies an innovation in international law, it is a desirable and beneficent innovation fully consistent with justice, with decent respect for the opinion of the world, with common sense which is of the essence of the law, and with the abiding purposes of the law of nations. ${ }^{38}$

In the first instance, Mr. President, this is a truly awe-inspiring and epoch-making occasion. For the first time in history we see a State in the dock. We behold the Government of what was a sovereign nation and most of the moving agents of its destructive malevolence placed as accused at the bar of mankind. The mystical sanctity of the sovereign State, shorn of the paraphernalia of pomp and power, is here arraigned before the judgment of the law. The salutary and indispensable doctrine that a State is capable of committing a criminal act and that it can become the subject of criminal responsibility, is here fully accepted. There was a time when international lawyers used to maintain that the liability of a State is, because of its sovereignty, limited to contractual responsibility. International tribunals have not accepted

\footnotetext{
${ }^{37}$ Ibid.

${ }^{38}$ Ibid.
} 
that view. They have repeatedly affirmed that a State can commit a tort; that it may be guilty of trespass, of a nuisance, of negligence. They have gone further. They have held that a State may be bound to pay what [is] in effect penal damages for failing to provide proper conditions of security to aliens residing within their territory. In a recent case decided in 1935 between the United States and Canada an arbitral commission, with the concurrence of its American member, decided that the United States were bound to pay what amounted to penal damages for an affront to Canadian sovereignty. ${ }^{39}$ On a wider plane the Covenant of the League of Nations, in providing for sanctions, recognized the principle of enforcement of the law against collective units-such enforcement to be, if necessary, of a penal character. There is thus nothing startlingly new in the adoption of the principle that the State as such is responsible for its criminal acts. In fact, save for the reliance on the unconvincing argument of sovereignty, there is in law no reason why a State should not be answerable for crimes committed on its behalf. In a case decided nearly one hundred years ago Dr. Lushington, a great English Admiralty judge, refused to admit that a State cannot be a pirate. ${ }^{40}$

History, very recent history, does not warrant the view that a State cannot be a criminal. On the contrary, the immeasurable potentialities for evil inherent in the State in this age of science and organization would seem to demand imperatively means of repression of criminal conduct even more drastic and more effective than in the case of individuals. In so far therefore as the Charter has put on record the principle of the criminal responsibility of the State it must be applauded as a wise and far-seeing measure of international legislation.

Admittedly, the conscience shrinks from the rigours of collective punishment, which fall upon the guilty and the innocent alike-although, it may be noted, most of those innocent victims would not have hesitated to reap the fruits of the criminal act if it had been successful. Humanity and justice will find means of mitigating any injustice of collective punishment. Above all, much hardship can be obviated by making the punishment fall upon the individuals directly responsible for the criminal conduct of the State. It is here that the Powers who framed the Charter took a step which justice, sound legal sense and an enlightened appreciation of the good of mankind must acclaim without cavil or reserve. The Charter lays down expressly that there shall be individual responsibility of the defendants for the crimes, including the crime against the peace, committed on behalf of the State. The State is not an abstract entity. Its

\footnotetext{
${ }^{39}$ See Trail Smelter Case (US v Canada), 3 RIAA 1905 (1935).

${ }^{40}$ See The Serhassan Pirates, (1845) 166 E.R. 788, 2 W. Rob. 354.
} 
rights and duties are the rights and duties of men. Its actions are the actions of men. It is a salutary principle of the law that politicians who embark upon a war of aggression should not be able to seek immunity behind the intangible personality of the State. It is a salutary legal rule that persons who, in violation of the law, plunge their own and other countries into an aggressive war, do so with a halter round their necks.

The principle of individual international responsibility for offences against the law of nations is not altogether new. It has been applied not only to pirates. The entire law relating to war crimes-as distinguished from the crime of war-is based on that principle. The future of international law and, indeed, of the world, depends on its application in a much wider sphere-in particular in that of safeguarding the peace of the world. There must be acknowledged not only, as in the Charter of the United Nations, fundamental human rights, but also, as in the Charter of this Tribunal, fundamental human duties. Of these none is more vital or more fundamental than the duty not to vex the peace of nations in violation of the clearest legal prohibitions and undertakings. If this is an innovation, then it is one which we are prepared to defend and to justify. It is not an innovation which creates a new crime. International law had already, before the Charter was adopted, constituted aggressive war a criminal act.

There is therefore in this respect no substantial retroactivity in the provisions of the Charter. It merely fixes the responsibility for a crime, clearly established as such by positive law upon its actual perpetrators. It fills a gap international criminal procedure. ${ }^{41}$ There is all the difference between saying to a man: "You will now be punished for an act which was not a crime at the time you committed it", and telling him: "You will now pay the penalty for conduct which was contrary to law and a crime when you executed it though, owing to the imperfection of international machinery, there was at that time no court competent to pronounce judgment against you." If that be retroactivity, we proclaim it to be most fully consistent with that higher justice which, in the practice of civilized States, has set a definite limit to the retroactive operation of laws. Let the defendants and their protagonists complain that the Charter is in this as in other matters an ex parte fiat of the victor. These victors, composing as they do the overwhelming majority of the nations of the world, represent also the world's sense of justice which would be outraged if the crime of war, after this Second World War, were to remain unpunished. In thus interpreting, declaring and supplementing the existing law they are content to be judged by the verdict of history. Securus judicat orbis terrarum. In so far as the Charter of this

\footnotetext{
${ }^{41}$ Speeches of the Chief Prosecutors, supra note 3, at 58.
} 
Tribunal introduces new law, its authors have established a precedent for the future-a precedent operative against all, including themselves. In essence that law, rendering recourse to aggressive war an international crime, had been well established when the Charter was adopted. It is only by way of corruption of language that it can be described as a retroactive law.

There remains the question, with which it will not be necessary to detain the Tribunal for long, whether these wars launched by Germany and her leaders in violation of treaties, agreements or assurances, were also wars of aggression. ${ }^{42}$ If the proof of that particular charge were unduly onerous or complicated, we might be inclined to dispense with it altogether. It would be enough for the Prosecution to show that these wars were in violation of international treaties, agreements and assurances and thus came fully within the orbit of Count Two of the Indictment. However, the proof that these wars were also wars of aggression does not present a difficulty. A war of aggression is one which is resorted to in violation of the international obligation not to have recourse to war or, in cases in which war is not totally renounced, when it is resorted to in disregard of the duty to utilize the procedure of pacific settlement which a State has bound itself to observe. There was, in the period between the two World Wars, a divergence of views among jurists and statesmen whether it was preferable to attempt in advance a legal definition of aggression or to leave to the States concerned and to the collective organs of the international community freedom of appreciation of the facts in any particular situation that might arise. Those holding the latter view urged that a rigid definition might be abused by an unscrupulous State to fit in with its aggressive design; they feared, and the British Government was for a time among those who thought so, that an automatic definition of aggression might become "a trap for the innocent and sign-post for the guilty". Others held that in the interest of certainty and security a definition of aggression, like a definition of any crime in municipal law, was proper and useful; they urged that the competent international organs, political and judicial, could be trusted to avoid in any particular case a definition of aggression which might lead to obstruction or to an absurdity. In May 1933 the Committee on Security Questions of the Disarmament Conference proposed a definition of aggression on the following lines:

The aggressor in an international conflict shall, subject to the agreements in force between the parties to the dispute, be consid-

\footnotetext{
${ }^{42}$ Speeches of the Chief Procesutors, supra, note 3, at 57-9.
} 
ered to be that State which is the first to commit any of the following actions:

(1) declaration of war upon another State; ${ }^{43}$

(2) invasion by its armed forces, with or without a declaration of war, of the territory of another State;

(3) attack by its land, naval, or air forces, with or without a declaration of war, on the territory, vessels, or aircraft of another State;

(4) naval blockade of the coasts or ports of another State;

(5) provision of support to armed bands formed in its territory which have invaded the territory of another State, or refusal, notwithstanding the request of the invaded State, to take in its own territory all the measures in its power to deprive those bands of all assistance or protection. ${ }^{44}$

The various treaties concluded in 1933 by the Union of Soviet Socialist Republics and other States followed closely that definition. So did the Draft Convention submitted in 1933 by His Majesty's Government in the United Kingdom to the Disarmament Conference.

However, it is unprofitable to elaborate here the details of the problem or of the definition of aggression. It is to be hoped that this Tribunal will not allow itself to be deflected from its purpose by attempts to ventilate in this Court what is an academic and, in the circumstances, an utterly unreal controversy as to what is a war of aggression. There is no definition of aggression, general or particular, which does not cover abundantly and irresistibly and in every material detail the premeditated onslaught by Germany upon the territorial integrity and the political independence of so many States. ${ }^{45}$ This has been, during the first fortnight of this trial, the main burden of the evidence presented on behalf of the Prosecution under the first two Counts of the Indictment.

There is, in very abstract theory, only one defence to the crime, of which the defendants stand accused jointly and severally, of planning, preparing, initiating and waging wars of aggression which were also wars in violation of specific and general international obligations. That answer is that these were wars in self-defence. We do not know whether the defendants and their advisers will

\footnotetext{
${ }^{43}$ Ibid.

${ }^{44}$ Politis Report, supra note 18.

${ }^{45}$ Speeches of the Chief Prosecutors, supra note 3, at 60.
} 
choose the path of challenging, with the mixture of cynicism and naivety to which other nations have now become accustomed on their part, the natural meaning of words. German leaders may have been used to inflicting brazen language of arrogant and patent insincerity upon their own people cut off from the outer world and incapable of gauging its astonished and angry reactions. But of what use is it to appeal before this Tribunal and before the world to the notion of self-defence-unless a carefully thought out design of aggression executed over a period of years is consistent with self-defence, unless the right to live includes the right to destroy the lives of others, unless the extension of the Lebensraum is a primordial right rising sovereign over all accepted notions of law, of morals, of decency, and of compassion?

It might be said by or for the defendants that in the authoritative declarations preceding and accompanying the signature and the ratification of the General Treaty for the Renunciation of War self-defence was not only recognized as an inherent and inalienable right of the parties to the Treaty, but also that they reserved for themselves the right to judge whether circumstances called for the exercise of that right. There have been some who considered the reservation of self-defence so interpreted as destructive of the purpose and of the legal value of the Treaty. If Germany, under the Pact of Paris, was entitled to have recourse to war in self-defence and if she was entitled to determine in what circumstances she was permitted to exercise the right of self-defence, can she ever be considered as having violated the solemn obligations of the Treaty? The clear answer to that specious argument is that a solemn treaty subscribed to by more than sixty nations is not a scrap of paper devoid of meaning. The Treaty did not-no treaty could-take away the right of self-defence. Neither did it deprive its signatories of the right to determine, in the first instance, when there is danger in delay and when immediate action in face of an attack is imperative. ${ }^{46}$ But the State thus acting is not the ultimate judge of the propriety and of the legality of its conduct. It is answerable if it abuses its discretion, if it avails itself of the faculty of self-defence as an instrument of conquest and lawlessness, if, in a futile attempt at deception which is not even intended to deceive, it twists the natural right of self-defence into a weapon of predatory aggrandizement and lust. ${ }^{47}$ This is what the German leaders have done. Any appeal on the part of the defendants to the right of self-defence would be no more than further evidence of that guilty design which underlay their transgressions against the peace of the world.

\footnotetext{
${ }^{46}$ Speeches of the Chief Prosecutors, supra note 3, at 55.

${ }^{47}$ Ibid., at 56.
} 
This, in general outline, is our case under Part II of the Indictment. We shall ask the Tribunal, after it has heard the full evidence presented by the Prosecution, to find that the defendants are guilty of the crime against the peace by planning, preparing, initiating and waging wars of aggression in violation of international treaties, agreements and assurances. We shall ask the Tribunal to find that they are guilty of this crime of war which, in turn, proved the source and the occasion for the horrors of war crimes and crimes against humanity. This is not a vindictive trial of vengeance and retribution. The lives of these defendants mean little when put against the calamities of suffering and death which they inflicted upon millions of men, women and children. But justice must be vindicated so that this trial and this Tribunal may make their proper contribution towards restoring the hope and the faith of men of good will that the rule of law, and all that it means and stands for, shall not perish from this earth.

\section{Closing speech-Introductory}

Members of the Tribunal: with the speeches for the defence and with the concluding addresses of the prosecution this, the greatest and one of the most significant trials in history has entered upon its final stage. We now see clearly the pattern of this trial which, in the weighty words which you, My Lord, uttered at the opening session, "is unique in the history of the jurisprudence of the world" and which "is of supreme importance to millions of people all over the globe". As the wearying months of the proceedings were passing-and they have been wearying not only by reason of the duration of the trial but also, and incomparably more so, because of the nature of the terrible story which unfolded itself-as those months passed it was becoming abundantly clear to those in this Courtroom and to the world at large that, against, it would seem, overwhelming odds, this Court was triumphantly, by common consent, asserting its authority as a venerable instrument of law and justice. According to the Four Power Agreement of 8 August, 1945, which established this Tribunal and which framed its Charter, this was to be an International Military Tribunal. If that name conveyed to some circles, including the defendants, the impression of a court martial, bound by rigid rules to follow a summary procedure neglectful of principles of fair trial and wielding an arbitrary military law, then this impression was soon dispelled. The Charter designated this Court to be a Military Tribunal because of the executive method of appointment, because the primary task of the Tribunal is to pronounce judgment in the matter of war 
crimes, i.e., offences laid down by the international law of war as expressed in international custom and in conventions concerned with rules of warfare, and because it was deemed desirable to make provision for an expeditious progress of the trial unhampered by obstructive technicalities. Yet, my Lord, seldom in history has a criminal court shown fewer characteristics of what is in the popular mind associated with purely military procedure. In fact, as the trial has been progressing there has been taking shape, in the hands of the Tribunal, a body of criminal procedure and rules of evidence which, it may be confidently asserted, will stand the test, however exacting, of any international enactment for safeguarding the rights of accused persons. As occasion arose, the Tribunal laid down rules as to examination and cross-examination, as to the use of affidavits, and as to the admissibility of evidence. These rules have been accepted by all concerned as fair, just, and reasonable. They have provided a most valuable precedent for any future International Criminal Court whether connected with the business of war or not. ${ }^{48}$ Fears which have often been expressed in this connection to the effect that differences of national conceptions of jurisprudence and methods of criminal trials may be a serious impediment in the way of the conduct of the proceedings and of the elucidation of the truth have proved unfounded. This is one of the indirect but important results of this State trial under the aegis of nations with widely differing systems of law.

Seldom, my Lord, have the inherent qualities of justice and law triumphed more conspicuously over inauspicious circumstances. On the face of it this was to be an ad hoc, improvised, military tribunal created by a treaty concluded inter se by four victorious Powers still in the flush of triumph in a most complete victory over a prostrate adversary and still in the flush of righteous anger over evil deeds of unprecedented compass and horror. It might have seemed that what they created was a political body thinly cloaked in the transparent garb of judicial authority and called upon to give effect to a political decision. Any such suspicion or impression vanished almost from the very outset of the trial. As the months passed it became clear even to the prejudiced mind that the proceedings before this Tribunal fully vindicated the exhortation which you, Mr. President, addressed at the opening Session to all concerned-the admonition that "there is laid upon everybody who takes any part in this trial a solemn responsibility to discharge their duties without fear or favour in accordance with the sacred

\footnotetext{
${ }^{48}$ On 17 July 1998, more than fifty years after the Nuremberg trial, the Rome Conference adopted the Statute of the International Criminal Court, 2187 UNTS 3. As of May 2012, 139 states have signed the Rome Statute, while it has received 121 ratifications.
} 
principles of law and justice."

Undoubtedly, the will of the victorious Powers-Powers representing over one-half of the civilized world-is responsible for the establishment of this Tribunal. But, essentially, this is a Tribunal administering the law of nations. As you have occasionally reminded us, my Lord, both in matters of wider import and in points of detail, this is a Tribunal of international law. On some questions, such as that of the plea of superior orders-a matter with which I propose to deal at some length later on-the Four Powers themselves clarified the existing law and lightened the task of the Tribunal by nipping in the bud a doctrine which tends to reduce the law to an absurdity. They also deemed it proper to lay down, with all requisite clarity, that the principle of individual responsibility which international law has invariably applied to war crimes proper is of general application with regard to acts which the law as it stood at the outbreak of the Second World War stigmatized as illegal and as criminal. But in general they left intact the competence of this Tribunal to apply international law in the full and unhampered exercise of its judicial independence. In particular the Tribunal will be called upon to pronounce upon questions of international law in passing judgment upon war crimes, that is to say, upon acts which the prosecution asserts to be contrary to indisputable rules and principles of international law. The very notion of a war crime is a conception of the law of nations, and it has properly been so treated by the defence. Whether the mass shootings of hostages is illegal and criminal is a question of international law; the accused maintain that it is in accordance with the law of nations. Whether forcible deportation of the inhabitants of occupied territory for compulsory labour for purposes directly connected with the conduct of war or for any other purpose is illegal and criminal is a question of international law; it has been maintained on behalf of the accused that, in modern conditions of warfare, this is not an act which is contrary to the law of nations. The killing of commandos who surrender as prisoners of war after the successful accomplishment of their mission has been represented on behalf of the accused as being in conformity with international law. Direct action of annihilation taken against the crews of merchantmen sunk without warning has here been claimed not to be contrary to the London Agreements respecting Submarine Warfare ${ }^{49}$ and to customary international law. The Tribunal will pass judgment upon these legal submissions. Admittedly it has not been claimed

\footnotetext{
${ }^{49} 1930$ International Treaty for the Limitation and Reduction of Naval Armament, Part IV, 112 LNTS 65, at 88; 1936 Procès-Verbal relating to the 1930 Rules of Submarine Warfare set forth in Part IV of the Treaty of London, 173 LNTS 353.
} 
on behalf of the accused that the murder of five to six million non-combatants in occupied territory could be reconciled with the letter or with the spirit of the laws of war, even in modern warfare. But it has been put forward as a sound legal proposition that the responsibility for this most terrible act in history does not rest either upon those who wielded paramount military power in occupied territory or upon those who were members of the Government under whose aegis these deeds of horror and shame were perpetrated, nor upon those who were direct associates of the man who alone, it is claimed, ordered these deeds to be done, nor finally, upon those who were moral and doctrinal and ideological authors of that act whose commission they prepared, induced, and applauded. Of this proposition of law the Tribunal, too, will be the judge. Similarly, these proceedings will provide an important occasion for judicial determination of the extent to which the plea of superior orders may be taken into account as an extenuating circumstance in meting out punishment.

If, my Lord, this view of the functions of the Tribunal is the correct view, then there is special significance attaching to the fact, which you and this Tribunal have repeatedly acknowledged, that this is an international court administering international law. It is true that the Tribunal is a creation of the Agreement of 8 August, 1945, and of the Charter; it is also true that, in a very substantial sense, the law of the Charter is the law of the Tribunal. It is mandatory upon the Tribunal to pronounce punishment for crimes laid down in Article 6 in accordance with any special provisions of the Charter such as in the matter of superior orders. But that mandate the Tribunal, being an international tribunal, is fulfilling within the framework of general international law. Having created this international Tribunal the contracting parties must be presumed to have authorized it to give judgment on the basis of international law. There is in this respect no difference between an international court established for the purpose of adjudicating upon a dispute between States and a tribunal created for a purpose like the present. For this reason we fully accept the implications of the statement made by you, Mr. President, at the opening Session of this Tribunal that "the four signatories, having invoked the judicial process, it is the duty of all concerned to see that the trial in no way departs from those principles and traditions which alone give justice its authority and the place it ought to occupy in the affairs of all civilized states." The sources of law on which, as an international court, this Tribunal is in the positions to rely are the same as those of any other international tribunal. They are, in the language of Article 38 of the Statute of the Permanent Court of International Justice:

(a) International conventions laying down rules expressly agreed upon by the 
parties. The rules thus agreed upon include all those specifically laid down in the Charter. They also comprise all the relevant treaties, such as the various Hague Conventions on the conduct of hostilities and the Geneva Convention of 1929 on the Treatment of Prisoners of War.

(b) International custom as evidence of the practice followed by States. This includes the customary rules of war which constitute the principal source of law in relation to the part of the indictment bearing on war crimes.

(c) General principles of law as recognized by civilized States. These, in the case before the Tribunal, will include in particular the general principles of criminal law-a source of law of special significance in connection with crimes against humanity.

Posterity will finally assess the place of this great trial in history. But it is clear already now that its effects will reach far beyond the punishment of the guilty. Issues larger than the fate of the twenty-one defendants are at stake. Of these issues, a conscientious and meticulous administration of international justice is not the least important. The Tribunal has resolved-and assuredly history will acclaim its decision-that this, and not the apprehension that this trial might become unduly prolonged, must be the decisive consideration. In the perspective of history it will matter little whether this trial has lasted six months or ten. What will matter will be the fact that by dint of sustained perseverance in face of very considerable physical fatigue this Tribunal has adhered to and with great patience went outside the safeguards of a fair and full trial as provided in the Charter; ${ }^{50}$ that it gave the procedural safeguards of the Charter a vitality of which few thought them capable; that an overwhelming mass of evidence not only was assembled but also sifted and clarified in examination, cross-examination, and re-examination; that no attempt was tolerated or, indeed, made to obtain evidence or admissions by sharp methods of surprise or intimidation; and that full protection was given to the defendants to the point of observing minutiae of form and address the finer meaning of which may possibly have been lost upon some of the accused accustomed to the rough jurisprudence of their own judicial practice. Thus the Tribunal has repeatedly refused to permit prosecuting counsel to ask questions in a form implying that the acts with which the accused are charged have already been adjudged to be crimes or violations of treaties.

\footnotetext{
${ }^{50}$ Closing Speeches of the Chief Prosecutors, supra note 3, at 34.
} 
However, it is possible that the unavoidable length of the trial may have the effect of blurring to some extent the general objects of this trial, and I intend, therefore, with your permission, my Lord, to devote this concluding speech for the prosecution to three matters. In the first instance we propose to put before the Tribunal our final submissions on the matters of law in connection with the charges brought against the accused and with the defence adduced on their behalf. Secondly, and principally, as the Tribunal will naturally expect the prosecution to deal with the case of each individual defendant in the light of the indictment, of the evidence produced in this Court and of the submissions of defending counsel, I intend to devote to this subject the greater part of the time allotted to me. Finally, it is essential in proceedings of this nature and importance to put on record both before this Tribunal and, indirectly, before the civilized world and the forum of history, the view of the prosecution and of the Governments on whose behalf we appear as to the bearing of this trial, of the Charter, of the Indictment and of the just judgment of the Tribunal upon the wider issues of international justice, international morality and international peace. In the long run the authority of the law and of the verdict given in its name must depend upon their approval by the enlightened and informed public opinion of the world. We are very confident that the judgment of this Tribunal will, also in this respect, be a contribution of the very highest value. In the meantime it is incumbent upon the prosecution to state their view on the subject, and I propose therefore to devote the concluding part of my address to this aspect of the case before the Tribunal.

\section{Closing Speech-Part I}

My Lord, all the accused in the dock stand indicted of some or all of the following crimes as laid down in Article 6 of the Charter: Crimes against the peace, war crimes, and crimes against humanity. In particular, with one or two possible exceptions, all the accused are charged with the commission as actual perpetrators, accomplices, or instigators of war crimes, namely, of violations of the laws and customs of war. The Charter provides that "such violations shall include, but not be limited to, murder, ill treatment, or deportation to slave labour or for any other purpose of civilian population of or in occupied territory, murder or ill treatment of prisoners of war or persons on the seas, killing of hostages, plunder of public or private property, wanton destruction of cities, towns and villages, or devastation not justified by military necessity." I propose to submit in the second Part of this address that, according to the 
evidence, all the accused, with the possible exception of the defendants Schacht and von Papen, stand convicted of one or more of these crimes. The charge of war crimes is the foremost and principal count of the Indictment, and it will be our submission that that count is by itself sufficient to seal the fate of these defendants. The remaining two charges of Article 6, those of crimes against the peace and of crimes against humanity, we consider to be good in law and absolutely unavoidable as a matter of conscience and of duty to the world, and if we were to-day called upon to frame the Charter which we adopted in August of 1945 we would not hesitate, with all the experience which we have now of the misunderstanding and the misrepresentation to which these two charges lend themselves-we would not hesitate to include them in the indictment. But there is no doubt that in the minds of some persons and circles, including counsel for the defence, these two charges of Article 6 have given rise to questioning of the legal basis and of the propriety of the indictment. It is with regard to these counts that the shrill argument of retroactivity and of post facto legislation has been raised repeatedly and insistently.

We do not propose to shirk the challenge of that argument. In the meantime, we attach the greatest importance to stating that if this were a trial with the exclusive purpose of exacting just punishment and retribution from the defendants, the charge of war crimes would serve that purpose amply, abundantly, and conclusively. We assert that, but for one or two exceptions, not one of the defendants would incur additional jeopardy to his person because of the charge of crimes against the peace or against humanity. So overwhelming is the charge of war crimes that we cannot even concede that the other two charges constitute to any substantial degree an aggravating circumstance likely to add to the penalties of the verdict to be given by the Tribunal. There are crimes the penalties for which cannot be increased because of some other crime. We had therefore to consider at a very early stage whether we ought to incur the danger of obscuring the very clearest of issues by coupling it with charges likely to be misunderstood or misrepresented. Every reason of convenience and opportunism counselled a simplification of the Indictment and the omission of the charges of crimes against the peace and crimes against humanity. Every consideration of principle and of wider duty counselled the contrary course. These reasons of principle and wider duty determined the four Governments to adopt Article 6 of the Charter in its present form. These two additional charges we are resolved to press with the utmost vigour. But we do not forget that they are additional, though not secondary, to the principal charge of the Charter-that of violations of the laws and customs of war. What are the war 
crimes of which the defendants are accused? They are many and manifold. ${ }^{51}$ They are enumerated, though only by way of illustration, in Article 6 of the Charter. They vary most considerably in the number of victims. There are the fifty murdered prisoners of war who escaped from Stalag Luft III; there are the hundreds of commandos and airmen put to death under orders transmitted under the personal responsibility of some of the defendants; there are tens of thousands of civilians shot as hostages in a campaign apparently intended to safeguard the security of the troops but in fact used for the liquidation of elements deemed politically undesirable; there are tens of thousands of sailors and passengers who perished in a piratical campaign of terror; there are tens of thousands of Polish and Czech intellectuals and Russian political workers murdered in pursuance of a systematic plan of liquidation; there are hundreds of thousands of prisoners of war, especially Russian prisoners of war, led to their doom by ill-treatment or by outright murder; there are hundreds of thousands of civilians who met their death because of the rigours and cruelties to which they were exposed in a foreign land where they were brought by force, torn from their kith and kin, to slave as direct helpers in a war against their own State; and there are the five million civilians who were murdered either outright or by the slower method of deliberate starvation for no other reason than that they were of Jewish race or faith.

Obviously, my Lord, the mere number of victims is not the only criterion of the criminality of an act. The majesty of death, the compassion for the innocence, the horror and the detestation of the ignominy inflicted upon man created in the image of God-these are not a fit subject for mathematical computation. Nevertheless, it is clear that, somehow, numbers are relevant. For this reason the principal war crime, in extent and intensity, with which the defendants are charged is the violation of the most fundamental, the most firmly established and the least controversial of all the rules of warfare, namely, that non-combatants must not be made the direct object of hostile operations. In particular, to use simpler language, they must not be killed or made to suffer in their persons or their liberty unless they wage war against the occupant or unless they break laws issued by him in accordance with international law. The Hague Convention No. IV on the Laws and Customs of War ${ }^{52}$ merely formulated that fundamental rule when it laid down, in the matter of belligerent occupation, that "family honour and rights, the lives of persons, and private

\footnotetext{
${ }^{51}$ Ibid.

521907 Hague Convention Respecting the Law and Customs of War on Land (1907 Hague Convention No. IV), 205 CTS 277.
} 
property, as well as religious convictions and practice, must be respected" (Article 46). The murdering, on the orders of the German Government whose members are here in the dock, in the territory occupied by its military forces whose leaders are here in the dock, the murdering of six million civilians in pursuance of a policy of racial extermination, as the result of and in connection with deportation for forced labour, in consequence of a policy of doing away with the intellectual and political leaders of the nations whose territories had been occupied, as the result of the application of terror through collective reprisals upon the innocent population and upon hostages-this killing of six million non-combatants is a war crime. Both imagination and intellect, bewildered and nauseated by the horror of the fate and of the sufferings of these countless victims, recoil from putting that greatest crime in history into the cold formula of war crimes as described in text books of international law. ${ }^{53}$ There is, therefore, a tendency, which is perfectly natural in the circumstances, to speak of these crimes as being crimes against humanity. So they are in the sphere of conscience and of morals. For the purposes of law, of the Indictment, and of this trial, they are war crimes pure and simple. We attach considerable importance to establishing that distinction. There may otherwise be a tendency, which has revealed itself in some quarters, to argue that these crimes are so terrible that they must be considered as being against humanity and to proceed to argue that as international law knows nothing of crimes against humanity the Indictment is in the nature of an innovation. Every consideration of justice, of decency, and of fitness of things requires that the matter be put outside the sphere of argument. These are war crimes pure and simple. There is every justification for brushing aside, with impatient and angry contempt, any suggestion of retroactive legislation so far as these crimes are concerned. There is, in international law, no shadow of retroactivity either about the Indictment so far as it concerns these crimes or about the decision of the Charter that their perpetrators are liable personally and individually. These are war crimes which, notwithstanding their enormity, are ordinary war crimes against the law of war in general and against the law of belligerent occupation in particular. They are war crimes irrespective of the locality where they were committed or even, to a substantial extent, of the nationality of the victims. The extermination in occupied Polish territory of millions of non-combatants is a crime against the laws of war and of belligerent occupation. It is entirely irrelevant whether these murdered non-combatants were of Polish nationality or of allied nationality or even of German nationality. They were crimes committed upon the civilian

\footnotetext{
${ }^{53}$ Closing Speeches of the Chief Prosecutors, supra note 3, at 60.
} 
population in occupied territory. Article 6 of the Charter refers expressly to the murder of the civilian population of or in occupied territory. It is equally irrelevant whether the crime, set afoot in occupied territory, was consummated there. Dutch nationals killed in extermination centres in Poland or Polish nationals killed in extermination camps on Czechoslovak soil were victims of war crimes committed in occupied territory. Let us not forget in this connection that, as a matter of law, Czechoslovakia must be considered to have been under enemy occupation at least as from October and December 1939, when France and Great Britain, respectively, recognized the Czechoslovak National Committee as the competent agency responsible, inter alia, for the reconstitution of the Czechoslovak Army. Weighty arguments may be adduced in support of the view that the enemy occupation began with the invasion of Czechoslovakia on March 15, 1939.

What is the responsibility of the defendants for this war crime? Part of this question is necessarily connected with what I propose to submit with regard to the guilt of each individual defendant, but there are questions of law which apply to the defendants in general and to groups of defendants and which bear not only upon this war crime, the greatest of all, but also upon others. There are, in the first instance, those defendants who, like Kaltenbrunner or Frank, were the direct agents, short of physical execution, of these crimes of extermination. Of those nothing further need be said here. Secondly, there are those who, like the defendant Streicher, were the instigators, the theorists, the propagandists and the approvers of these crimes. It is possible, though not probable, that the majority of the German people were not cognizant of the gigantic process of mass murder the proceeds of which fed their soap and hair-mattress factories and filled the vaults of their bank. But, my Lord, we submit that the way of that minority which conceived, ordered and executed the satanic plan was only made possible by years of steady incitement to and justification of murder on the part of this group of defendants. Those who decreed these murders would not have had the courage to order them, and those who executed and helped to execute these orders might have shrunk with the panic of amazement and fear from the terrible deed but for the fact that through the activity of these defendants a mental climate was created in Germany which made of these horrors an act of State, a measure of national purification, a grim but just necessity. Nearly eighty years ago Lord Acton, that great historian, in expressing his abhorrence of persecution and his deep conviction of the sanctity of human life, said: "The greatest crime is Homicide. 
The accomplice is no better than the assassin; the theorist is the worst." ${ }^{\prime 5}$ There has never been a greater and more tragic confirmation of these pregnant words. My Lord, I submit as a sound proposition of law and as a corollary of those general principles of law which the Tribunal is authorized to apply that direct responsibility for crime, in proportion to the potential and actual magnitude of the evil caused, attaches to persons guilty of incitement to and encouragement of such acts or what naturally leads to such acts.

There are, thirdly, those defendants who, in our submission, are guilty of the war crime of mass murder of the civilian population in occupied territory as well as of other war crimes by virtue of their membership of the Government under whose aegis and in the course of whose rule these deeds were perpetrated. This, my Lord, is not a question of any constructive responsibility. It is a criminal liability which flows from the patent absurdity of the plea that these accused knew nothing of these horrors. For these accused, as in the case of the defendant Goering, were closely associated in the conduct of the war with the persons to whom they now ascribe sole responsibility, and they were wielding powerful secret agencies of information of their own. The principle of collective responsibility of members of a government is not an artificial doctrine of constitutional law. The defendants do not in fact deny that had they known of these things they would have been criminally responsible by virtue of their continued membership of the Government. What they deny is any knowledge of these things. Can that denial be believed for an instant? Can it be believed with regard to any of these defendants? Can it be believed, in particular, with regard to acts which are a matter of common knowledge such as the avowed and publicly proclaimed policy of extermination through systematic starvation?

The same applies, my Lord, to their pretended ignorance of the unspeakable horrors of torture and extermination in concentration camps. We ask the Tribunal to declare that it does not lie with these defendants to shield themselves behind any lack of knowledge as to the conditions which prevailed in concentration camps during the war and as to the fact that one of the objects of these camps was to exterminate those sent to them. Torture and murder in concentration camps were not isolated acts of perverted sadists. They were part of a system. Such things are not done or permitted to be done on such a vast and uniform scale unless those in charge of the camps know that those in authority approve of these acts and desire them to happen. Is it a cause of astonishment to the defendants that-apart from those millions killed in a systematic

\footnotetext{
${ }^{54}$ Lord Acton, Historical Essays and Studies (MacMillan, 1907), at 506 (Letter to Bishop Creighton).
} 
action of extermination -tens and hundreds of thousands of civilian persons from occupied territories were put to death or maimed by torture in concentration camps? Surely this was not the case of an institution which degenerated into something which was entirely alien to the minds of those who conceived it. The whole doctrine of terror, of cruelty, of panic assiduously fostered, of bestiality and bestialization and debasement of human nature-all this, as a part of a political system of force and fear, was planned and approved by most of the defendants in the dock at the very outset of the régime.

Fourthly, we ask the Tribunal to declare, as a matter of interpretation of the customary and conventional law of belligerent occupation, that it is not open to the commanders of the army of occupation to relieve themselves of responsibility for the murder of the civilian population in countries which their forces temporarily conquered by permitting an official body which is part of the machinery of the State and over which they pretend to have no formal control, to execute or to prepare the execution of the criminal design. The commander of an army of occupation who fails to protect the civilian population against murder and deprivation of liberty is as guilty of a war crime as if he himself authorized the murder. The responsibility of the military commanders is in this respect absolute. They can attempt to avoid it by pleading superior orders-a plea which, as I shall submit, is in their case ineffectual by virtue not only of the Charter but also on wider grounds. They can attempt to escape liability by pleading ignorance of what was in fact happening to millions of victims of war crimes-an excuse which can be accepted only if we assume that the generals did not wish to know or to hear or to see things patent to all. The same applies to Governors of occupied territory such as the defendants Seyss-Inquart or Rosenberg. We urge that the Tribunal should finally reject as a matter of law the attempt to escape liability by means of the flimsy and clumsy device of the plea of a dual sovereignty in the occupied territory-of the parallel reign of law and murder, of the apparently orderly functioning of the authorities of occupation and the uncontrolled and uncontrollable reign of a gang of mass-executioners in the shape of an SS and a Gestapo. The military authorities which submit to such a transparent combination of law and lawlessness become accomplices of the crime. In view of this the isolated though frequent instances of direct participation of the armed forces in the process of extermination-witness the vain-glorious and inglorious part of the German army in the butchery in the Warsaw Ghetto-are a mere detail. Admittedly, in the course of a war cases may occur when, with the enemy advancing irresistibly and the disintegrating forces of occupation retreating in disorder, the power of the 
military commanders to prevent atrocities against the civilian population is reduced to a minimum. Extenuating circumstances of this nature were recently urged, against the majority of the Court, by the two dissenting Justices of the United States Supreme Court in the case of General Yamashita who was convicted and hanged for violation of the laws of war. ${ }^{55}$ In the case before this Tribunal murder-wholesale, planned, and systematic-became part and parcel of a firmly entrenched and apparently secure belligerent occupation.

This, then, my Lord, is the principal crime against the laws of war of which the accused, according to the evidence and according to the universally accepted principles of the law of war, are guilty in various degrees and in various capacities as I propose to show when I come to the individual defendants.

For obvious reasons counsel for the defence made no attempt to put somehow that major crime against the civilian population within the orbit of the law by using in relation to it the stock argument of changed conditions of modern warfare. But attempts of this nature have been made with regard to other war crimes. Of these three require special consideration before this Tribunal. They are the crime of deportation to Germany for forced labour, the crimes at sea in connection with submarine warfare, and, even more significantly, the shooting of commandos by virtue of orders transmitted and executed by some of the defendants.

The deportation of the civilian population for forced labour is, of course, a crime both according to international customary law and to conventional international law as expressed in the Hague Convention. Article 46 of Hague Convention No. IV enjoins the occupant to respect "family honour and rights" and "the lives of persons". Article 52 of the same Convention lays down that "services shall not be demanded from municipalities or inhabitants except for the needs of the army of occupation" and that "they shall be in proportion to the resources of the country, and of such a nature as not to involve the population in the obligation of taking part in the operations of war against the country." With these simple and categorical provisions we have to contrast the staggering dimensions of the operation which defendant Saucket directed and in which other defendants participated, the ruthlessness with which peaceful citizens were torn from their families, surroundings and employment, the manner in which they were transported, the treatment which they received on arrival, the conditions in which they worked and died in thousands and tens of thousands, and the kind of work which they were compelled to perform as direct helpers in

\footnotetext{
${ }^{55}$ See Yamashita v Styer, 327 U.S. 1, 90 L. Ed. 499 (1946), Justices Murphy and Rutledge dissenting.
} 
the production of arms, munitions and other instruments of war against their own country. ${ }^{56}$

This attempt to enslave the population of the occupied territory for purposes directly hostile to their own State is not a new page in German practice. In October 1916 the German Supreme Command issued orders providing for the deportation from Belgium to Germany of certain classes of persons. This decree was couched in terms suggesting that it applied only to idle and vagrant persons and that it had been adopted mainly as a measure for dealing with unemployment in Belgium. We are not mentioning this, my Lord, in order to rake up an unsavoury past. I mention it in order to draw attention to the fact that these German deportations in Belgium in 1916, although almost trifling when compared with the practice of deportation during the Second World War, drew upon themselves the horrified protests not only on the part of the Belgian people but also of neutrals. The United States of America, at that time scrupulously neutral, formally protested in a note addressed to Germany "against this action which is in contravention of all precedent and of those humane principles of international practice which have long been accepted and followed by civilized nations in their treatment of non-combatants in conquered territory". As the result that practice was abandoned within a year of its initiation. It may be noted that in a Legal Opinion issued by the Reich Chancellery prior to the deportation order of October 1916 it was declared that "under the law of nations the intended deportation of idle Belgians to Germany for compulsory labour can be justified if: (a) idle persons become a charge on public relief, (b) work can not be found for them in Belgium, (c) forced labour is not carried on in connection with operations of war" and that, hence, "their employment in the actual production of munitions should be avoided." It may also be noted that after the First World War the Commission of the German Reichstag which investigated charges of violations of the laws of war did not go further than to attempt, in specious argument, to bring the deportations within the four corners of the Hague Convention by maintaining that they took place with the view to relieving unemployment and were thus in accordance with the obligation which the Hague Convention imposes upon the belligerent to ensure "public order and safety" in the occupied territory. We submit, my Lord, that the deportation of civilians from occupied territory for forced labour abroad is not only a violation of international custom and treaties but also, in view of the sufferings and loss of life involved in the manner of its execution by Germany, a criminal violation of the law of nations. It has been suggested on

\footnotetext{
${ }^{56}$ Speeches of the Chief Prosecutors, supra note 3, at 61.
} 
behalf of the accused that that particular prohibition of international law has become obsolete in the face of modern developments of totalitarian warfare which requires the vastest possible use and production of goods and resources and that, in modern conditions, no occupant of enemy territory could possibly be expected to stultify his efforts by refraining from the exploitation to the full of the man-power available in occupied territory. ${ }^{57}$ (The Tribunal will have noticed that the same argument has been applied with regard to the wholesale exploitation, on a gigantic scale, of the economic resources of the occupied countries in violation of Article 52 of The Hague Convention which applies to requisitions the same principles as those applied to services.) We urge the Tribunal to condemn emphatically, as a matter of international law, any such attempt to adapt the conduct of war to changed conditions at the expense of the life, honour, dignity and property of the civilian population in occupied territory. Let the belligerent, if he finds it imperative, use his own resources and his own man-power to the very fullest. To enslave foreign nationals for that purpose is to commit a criminal act. The defendants must have sensed the unconvincing character of that particular attempt at justification. For, eventually, they fell back upon the plea of necessity. This is what the defendant Sauckel did when pressed in cross-examination. He did not, he admitted, enquire as to the position of international law on the subject. He had to do his duty by his own people. We know what the plea of necessity means in the hands of German politicians and strategists. It is the assertion of the right to live-and to live prosperously at the expense of the life and of the misery of others. The Tribunal will brush aside this clumsy attempt to reform international law-an attempt which is only in degree less frivolous than that made by the defendant Seyss-Inquart who explained that the compulsory use of the Dutch population for building the Atlantic fortifications was not contrary to law seeing that these civilians viewed with apprehension the prospects of the Allied invasion and were glad to be able to make their contribution towards preventing it.

Neither have the defendants a shadow of a right to invoke any material change of conditions in relation to their war crimes at sea in connection with submarine warfare-crimes which cost the lives of sixty thousand British seamen alone. ${ }^{58}$ The fact of a planned and systematic sinking of merchantmen without warning is proved by abundant evidence. This, my Lord, was not a piece of lawlessness embarked upon hesitatingly and reluctantly in the course of an unforeseen and uncontrollable development of events in which reprisals

\footnotetext{
${ }^{57}$ Ibid.

${ }^{58}$ Ibid.
} 
succeed counter-reprisals with the result that the border line between lawful retaliation and illegality becomes shadowy and elastic. It was a lawlessness conceived and initiated at the very outset of the hostilities. At the beginning, as in the case of the Athenia, it was concealed, clumsily and brazenly. Subsequently it became part of a system. Now, my Lord, we do not rest our case in this matter on the mere violation of the customary rules of warfare as embodied in the London Protocols of 1930 and 1936, fully subscribed to by Germany and prohibiting sinking without warning as well as sinking with warning but without proper provision for the safety of the passengers and crew. ${ }^{59}$ We do not wish to be entangled in the meshes of the seemingly interminable controversy which agitated the minds of lawyers and governments in the course of the First World War, whether the fact of defensive armament of merchantmen made impossible the observance of the customary rules of international law (as they were subsequently embodied in the London Protocols); whether in practice and in fairness no distinction is possible between offensive and defensive armament; and whether the defensive armament of and anticipatory offensive action by merchantmen were not in themselves the necessary answer to and a precaution against illegal sinking. For the guilt of the German Naval Command does not rest alone on the proved fact of sinking without warning. The evidence which has been produced in this Court shows that, also in this respect, the determination to throw over, brutally and with a cynicism accentuated by the studied secrecy and ambiguity of apocryphal orders, an established rule of war conceived for the protection of non-combatants. Orders were given that no attempts should be made to rescue survivors; orders were issued which could be interpreted and were in fact interpreted as meaning that steps ought to be taken to prevent the shipwrecked from surviving; and orders were framed for the use of weapons of destruction calculated to ensure the rapid sinking of ships so that there should be no question of survivors. ${ }^{60}$ The Court has heard reasons why these orders were deemed desirable and excusable. Modern conditions as shown in the ubiquitous presence of hostile aircraft render the work of rescue dangerous for the submarines; the same modern conditions make it probable that survivors will summon forces likely to attack the submarine; and the modern conditions of a totalitarian war coupled with the supreme importance for the enemy State of the mercantile marine require that no crews should be left to man it and that an atmosphere of terror should discourage others from joining it. We urge the Tribunal to consign, with the utmost rigour,

\footnotetext{
${ }^{59} \mathrm{Ibid}$.

${ }^{60} \mathrm{Ibid}$.
} 
these attempts at modernizing rules of war to the category where they properly belong, namely, to the category of crime pure and simple. The same applies, my Lord, to the orders, for which the former chiefs of the Germany Army and Navy cannot escape responsibility, relating to the shooting of commandos. The evasive and surreptitious manner in which these orders were drafted, transmitted and executed shows the conviction of guilt which they created in their authors. Witness the contradictory and unconvincing explanations given in this Court such as that the order may well have been one of legitimate reprisals for the close combat practice of the British commandos or that those who handed over the brave attackers of the Tirpitz to the Gestapo to be shot at dawn, one by one, without trial and without warning of their impending execution, did not know and were not reasonably expected to know what fate awaited them. The Tribunal will assess these excuses at their proper value. But we urge the Tribunal to repudiate and to condemn the doctrine, which has been put forward on behalf of the accused, that that new form of attack by commandos and parachutists, combined with the innovation introduced by the advent of aircraft, permits a belligerent to kill prisoners of war who surrender unconditionally. This was the law which was put forward tentatively before the Tribunal on behalf of the defendants-the doctrine that as the attackers knew in advance that they would have to surrender they relinquished the right to be treated as prisoners of war and that their life was forfeit. This kind of adaptation of international law to new conditions and instrumentalities of war must be solemnly branded as criminal. The sanctity of life of the soldier in uniform who surrenders after the completion of his mission and who is not guilty of a war crime committed prior to his capture is and must remain an absolute principle of international law. Those who trample upon it in disregard of law, humanity and chivalry must pay the penalty. ${ }^{61}$

With regard to the prisoners of war killed on their way to escape, the defendants concerned admit that this act amounted to murder pure and simple. They say that they disapproved of it-though there is no evidence of any emphatic action of theirs in that sense. However that may be, we put it forward as an accurate proposition of law that the active chiefs of the armed forces bear a distinct personal responsibility of a general character for the fate of prisoners of war whom they have made captive. That responsibility is additional to that of the belligerent government. Clearly they are not responsible for every individual violation of the law in relation to prisoners of war. But they are liable for any systematic failure to punish such violations; they are liable for

\footnotetext{
${ }^{61}$ Ibid., at 62.
} 
the toleration of and the acquiescence in a system which makes such breaches possible. A military chief who tolerated a system in which prisoners of war were handed over, under any pretext whatsoever or for any reason whatsoever, to an organization whose very essence was murder and terror and lawlessness cannot avoid responsibility. The safety and well-being of prisoners of war is the responsibility of the military authorities. This is not only an obligation of honour; it is a clear legal duty. In the case of the murder of prisoners of war nothing short of a determined protest, of an insistence on the punishment of the guilty and of assurances for the prevention in the future of any outrages of a similar character would have sufficed to reduce their responsibility or to relieve them of it. We submit that the same principle of law applies to the proved barbarous treatment of Russian prisoners of war. No serious attempt has been made by the defence to challenge the figures which the prosecution submitted on this count-the terrible figure of four hundred thousand Russian prisoners of war who died as the result of maltreatment or outright murder.

My Lord, I am not concerned in this part of my submission to survey the entire field of war crimes with which the accused are charged and which we believe the evidence has substantiated to an overwhelming extent. I am here concerned only with the question of the relation of war crimes to the Indictment as a whole and with those particular war crimes with regard to which we deem it desirable that the Tribunal should authoritatively declare the existing law with all requisite clarity. I pass therefore over the lamentable series of other war crimes arising out of seizure, confiscation and destruction of private and public property, of pillage, plunder, and destruction. These will come for review in connection with the cases of the individual defendants. These crimes have not been in the forefront of the Indictment or, generally, of public reprobation for the reason that, vast and unprecedented as these spoliations and depredations are, they pale before the horror of the irretrievable destruction of millions of lives. Property can be rebuilt, compensated and restored. Life cannot-though it must never be forgotten that spoliation, plunder and devastation were indirectly responsible, on the very largest scale, for irreparable loss of life. Neither shall I dwell here upon the war crimes which took place as the result and in the wake of the initial illegality of purported annexation of French and Polish territory. That wanton act, for which the defendants as members of the Government were responsible and in which the defendants in their capacity as military chiefs participated, was responsible, among others, for the criminal impressment of the nationals of these countries as members of the German armed forces. Trials have recently taken place in 
which members of German Military Courts were indicted for sentencing to death persons who, thus illegally impressed, deserted from the German army. The present defendants cannot escape ultimate responsibility for these crimes.

There are, however, two categories of most serious offences with regard to which the defendants have invoked existing law and practice and which nevertheless clearly belong to the heinous category of war crimes at their worst. The first is the mass shooting of hostages. The overwhelming majority of legal opinion as voiced in text books has expressed itself emphatically against the taking of hostages for any purposes whatsoever. Some believe that hostages may be taken for the purpose of ensuring with their presence the safety of buildings and conveyances exposed to danger. The Hague Convention is silent on the matter. There is no writer of repute who considers to be consistent with international law the killing of hostages as a reprisal for acts of which they are clearly innocent. Such scant support as exists in favour of killing hostages has come from Germany. During the Franco-Prussian war she initiated that practice and she pursued it with vigour during the First World War. Her action was defended by some German professors and by the Commission appointed by the German Reichstag to investigate charges of violations of the laws of war by Germany. But even those who were prepared to justify the German action in the matter agreed that there are clear legal limitations to the extraordinary and revolting measure of killing hostages. In particular, it must not be flagrantly contrary to the principle that collective punishments are prohibited. And it must be wielded with extreme caution and restraint. In the Second World War the German Government and the German military and occupation authorities contemptuously brushed aside these principles. The taking of hostages became not only a method of ensuring by terror the safety of and respect for German troops. It became part of the terror itself. More than that, directed as it was predominantly against communists and other politically suspect elements, it became a weapon of political extermination. We maintain that the murdering of hostages on this unprecedented scale became part and parcel of the German conduct of war and of the German machinery of belligerent occupation. We assert that the leading members of the German High Command and of the German Government are directly responsible for these murders. They have admitted and justified in this Court the authorship of orders directing ruthless terrorization of the population as part of a system of security. The killing of fifty thousand hostages was part of that system. We ask the Tribunal to declare that there is no warrant in existing international law for the proposition that hostages may be killed for the acts and omissions 
of others; that, possibly-although we admit that possibility with the very greatest hesitation-such action may be excused in case of extreme necessity when the security of the army of occupation is exposed to danger of a most serious character which cannot otherwise be averted; and that resort to it on the scale adopted by the German High Command and the German occupation authorities with the knowledge and approval of the German Government in the years 1940 to 1945 constitutes a war crime differing only in extent from others which horrified and nauseated the civilized world in the Second World War.

Finally, although we do not wish to ask this Court to pronounce upon questions of law which were not fully settled before the Second World War and which the war itself did little to clarify, we will ask the Tribunal to declare that aerial bombardment for the sole purpose of terrorizing the civilian population is unlawful and a crime. We are conscious of the as yet unsolved complexities of the problem of aerial bombardment. We realize that the Hague Rules of Air Warfare adopted in 1923 did not secure ratification. We know that the bombardment of centres of civilian population as begun by Germany in 1940 was followed by the allied attacks upon German centres of industry and communications on a very large scale. But we feel fully justified in asking the Tribunal to declare as an uncontroverted rule of law that aerial bombardment of towns and cities for the mere purpose of instilling terror into the civilian population of the enemy State and without giving it the opportunity to seek places of safety is a war crime and a violation of the most fundamental principle of warfare which prohibits armed attack upon non-combatants as the exclusive target of the operation. We assert that as a matter of international law the aerial bombardment of Rotterdam and of Russian and Polish towns following upon the undeclared launching of hostilities, is a war crime for which some of the defendants in the dock must bear responsibility.

My Lord, I have surveyed the main legal aspects of the principal part of the Indictment, namely, of war crimes, and in particular those relating to the extermination and murder of the inhabitants of occupied territory. These war crimes, we submit, have been abundantly proved by the evidence in relation to the various defendants acting in their various capacities. The legal position with regard to this part of the Indictment is clear and uncontroverted. It was not challenged in the general speech for the defence. It was ignored there. The one general speech for the defence- that of Professor Jahrseiss-was devoted exclusively to what was apparently considered to be the easier subject of the criminality of wars of aggression, of the mischiefs of retroactivity in criminal legislation, of the alleged novelty of the principle of the responsibility of the 
agents of the State for crimes committed on behalf of the State, and of the metaphysics of the doctrine of sovereignty. There is no trace of retroactivity about war crimes. There is no novelty about the principle that- barring the question of superior orders, which has been settled by the Charter and which I will deal with in due course-war criminals are individually responsible for their transgressions. There is no innovation implied in the claim of the belligerents to try enemy nationals for war crimes-the only departure from precedent in this case being in favour of the defendants, namely, that instead of being tried by the summary process of a court martial established by a single belligerent they are arraigned before an authoritative tribunal of unimpeachable competence and impartiality sitting in open court and affording the accused the greatest possible latitude in presenting their defence.

My Lord, if the object of this trial were merely to exact just retribution from the defendants, it would not have been necessary for us to go outside the charge of war crimes. We should not have prolonged these proceedings and we would have done nothing which might have encouraged irrelevant controversy by introducing the two other charges contained in Article 6 of the Charter. But this is not an ordinary criminal trial intended to bring upon twenty persons the full penalty of the law. As I have said, my Lord, we have anxiously considered in the Summer of 1945 whether we should be justified in including charges likely to confuse the principal aspect of the indictment. The Tribunal will have noted how adroitly that principal charge was ignored in the only speech for the defence. And the historian will note that contemporaneous criticism of these proceedings as a whole was based almost exclusively upon the parts of the Indictment charging the accused with crimes against the peace and crimes against humanity. Yet the Four Powers came to the conclusion that it would be a dereliction of duty to yield in this matter to shortsighted considerations of convenience and expediency. For, in a very real sense, the crime of war had become the parent of and the opportunity for the war crimes. In addition, it had become responsible for the deaths of ten million lawful combatants and for bringing to the very brink of ruin the material structure of our civilization. Ought we to have forborne to bring home to these defendants-and, indeed, to the world at large - that existing law stigmatizes wars of aggression to be a crime and that international law neither is nor need be powerless to exact from the guilty just punishment for this, the greatest of all, crimes? Ought we to have forborne to claim for international law the power, which is inherent in its very nature, to vindicate effectively the rights of man against the cruelty and barbarity of his own State and to penalize crimes against humanity which, with 
fatal necessity, become the source and the starting point of the crime of war? The Charter has provided a full answer to these questions.

I will deal, first, in the light of the evidence and of the submissions of defence counsel, with the general aspect of the charge of crimes against the peace. The speech for the defence on the subject was free of ambiguity. The learned counsel submitted that though the Kellogg-Briand Pact and the other international declarations and treaties rendered aggressive war illegal, they did not make it criminal; that they could not have done so because any such attempt would be contrary to the sovereignty of States; that even if they had done so the entire system of prohibition of war had collapsed before the outbreak of the Second World War and therefore ceased to be law; that, in any case, these treaties were not taken seriously by numerous writers and politicians and were not entitled to be treated seriously seeing they contained no provision for coping with the problem of the ${ }^{62}$ peaceful change of the status quo; that, further, there could be no question of a criminal-or even unlawful-breach of the Pact of Paris for the reason that that Treaty left to each State, including Germany, the right to determine whether it was entitled to go to war in self-defence; that the State could not become the subject of criminal responsibility; that, if that proposition were not admitted, the crime was one of the German State and not of the individuals who directed its actions; and that in any case there could have been no question of individual responsibility because in the German State which launched that war upon the world there was no will of individuals but one sovereign, uncontrolled and final will-that of the Dictator. ${ }^{63}$ This, my Lord, I believe to be a truthful summary of an argument richly supported by references to writers, carefully selected and sifted, and by interesting appeals to general jurisprudence and to European conceptions of law.

My Lord, it would be quite proper to say that this entire line of argument is beside the point and cannot be heard in this Court inasmuch as it is in contradiction to the Charter. For the Charter lays down expressly that the planning, preparation, initiation, or waging of a war of aggression or of a war in violation of international treaties, agreements, or assurances shall be considered crimes coming within the jurisdiction of the Tribunal. It would appear, therefore, that the only way in which the accused can escape liability is to show to the satisfaction of the Tribunal that these wars were not wars of aggression or in violation of treaties. They have not done that. This being so, what is the purpose of the argument which has been advanced on their

\footnotetext{
${ }^{62} \mathrm{Ibid}$, at 53 .

${ }^{63}$ Ibid., at 54.
} 
behalf? Is it to deny the jurisdiction of this Tribunal in this matter on the ground that, being an international Tribunal, it has no competence to adjudicate upon an Indictment which, on the face of it, is contrary to fundamental notions of international law? Or, what is more probable, is it a political appeal to an outside audience which is easily impressed by the complaint that the accused are being made the object of ex post facto legislation? ${ }^{64}$

I submitted, my Lord, in the opening statement which I made last December that although, of course, we fully realize that the Charter is the law of the Tribunal, it is incumbent upon us to attempt to answer this important part of the case for the defence. I am anxious not to take up the time of the Tribunal by repeating what I said in the opening statement on the change effected in the position of war in international law as the result of the long series of treaties, in particular the General Treaty for the Renunciation of War. I submitted that this Treaty, one of the most generally signed international treaties, established a rule of international law with a solemnity and clarity which is often lacking in customary international law; that the profound change which it produced was reflected in weighty pronouncements of governments and statesmen; that it rendered illegal recourse to war in violation of the Treaty; and that there is no difference between illegality and criminality in a breach of law involving the deaths of millions and an attempt at the very foundations of civilized life. Neither do I propose to take up the time of the Tribunal by answering in detail the fantastic chain of legal argument put forward by the defence such as that that Treaty had no effect attributed to it by its signatories on the ground that it was received in some quarters with disbelief or cynicism. Even more extraordinary, to ordinary legal thinking, is the reasoning that in any case that Treaty-and the other treaties and assurances which followed it - ceased to be legally binding by 1939 because by that time the entire system of collective security had collapsed. The fact that the United States declared its neutrality in 1939 was cited as an example of the collapse of the system of collective security, as if the United States had been under any legal obligation to act otherwise. In any case what is the relevance of the fact that the system devised ${ }^{65}$ to enforce these treaties and to prevent and to penalize criminal recourse to war failed to work? Did the aggressions of Japan and Italy, followed by the German aggressions against Austria and Czechoslovakia, deprive these treaties and obligations of their binding effect for the reason that these crimes achieved a temporary success? Since when has the civilized world accepted the principle that the temporary

\footnotetext{
${ }^{64}$ Ibid.

${ }^{65} \mathrm{Ibid}$., at 54 .
} 
impunity of the criminal deprives the law of its binding force and gives the imprimatur of legality to his crime? It will be noted, incidentally, that both in the case of the Japanese and Italian aggressions the Council and the Assembly of the League of Nations denounced these acts as violations both of the Covenant and of the General Treaty for the Renunciation of War and that in both cases sanctions were decreed. ${ }^{66}$ The astonished and angry reaction of the world to both these aggressions was not such as to lend credence to the view that the obligation to refrain from aggressive war had lost its legal or moral force. If the Italian onslaught on Abyssinia had taken place in 1914 there would have been sympathy with the victim and, probably, disapproval of the annexation, but the conquering State would have been considered to act within its legal rights. Contrast with it the reaction of the world to the Italian challenge in invading Abyssinia in 1935. That contrast is the measure of the state of the law and of the opinion of the world at that time on the subject of war of aggression. It is characteristic that counsel on behalf of the accused leaders of the principal Axis Power deemed it fit to invoke the repeated successful violations of the law on the part of the Axis Powers as a reason for the alleged obsolescence of the law which they defied and outraged. We maintain that the prohibition and the criminality of aggressive war were as much part of the juridical and moral conscience of the civilized world in the year 1939 as they were immediately after the enactment and acceptance of the various instruments outlawing aggressive war. Article 6 of the Charter which instructs the Tribunal to treat as crimes wars undertaken in violation of these instruments is declaratory of the existing law.

My Lord, one would have expected that considerations of good taste would have suggested to German counsel the impropriety of adducing the repeated and previously successful violations of treaties by the Axis Powers as a reason for the lapse of the legal validity of those treaties. One would also have thought that similar considerations of delicacy would have suggested to German counsel the inadvisability of referring in this connection to the question of self-defence. For not even the German Government presided over by Adolf Hitler had the naïve effrontery to present this war-even before the German people-as a war of self-defence. Possibly what the accused say is not that that war was one in self-defence, but that as the Pact of Paris not only left intact the right of self-defence but also the sovereign right of each State to determine whether recourse to war in self-defence was justified in the circumstances, it did not in fact contain any legal obligation at all and could not therefore be broken. ${ }^{67} \mathrm{My}$

\footnotetext{
${ }^{66} \mathrm{Ibid}$, at 55.

${ }^{67}$ Ibid.
} 
Lord, whatever may be the connotation in which this argument of self-defence has been adduced and however farfetched and inaccurate it may prove upon examination, it is a plea which we are not at liberty to ignore. In a case in which the launching of the greatest and the most disastrous aggressive war in history is part of the indictment, the judgment of this Tribunal is a proper opportunity for condemning finally and authoritatively the abuse of an otherwise legitimate and proper legal conception for justifying the greatest crime of which a State is capable. It is true that in the authoritative declarations preceding and accompanying the signature and the ratification of the General Treaty for the Renunciation of War self-defence was not only recognized as an inherent and inalienable right of the parties to the Treaty; they reserved for themselves the exclusive right of judgment as to whether circumstances called for the exercise of that right. Was the reservation of self-defence thus defined destructive of the purpose and the legal value of the Treaty? If Germany was entitled to have recourse to war in self-defence and if she was entitled to determine in what circumstances she was permitted to exercise the right of self-defence, can she ever be considered as having violated the solemn obligation of the Treaty? To this question counsel for the defence gave a clear answer in the negative. This answer amounts to an assertion that that solemn Treaty subscribed to by more than sixty nations is a scrap of paper devoid of meaning. It amounts to an assertion that every prohibition or limitation of the right of war is a mere scrap of paper if it expressly provides for the right of self-defence. We hope that the Tribunal will emphatically consign that parody of legal reasoning to where it properly belongs. Neither that particular Treaty nor any other treaty intended to-or could-take away the right of self-defence. Neither did it deprive its signatories of the right to determine, in the first instance, whether there is danger in delay and whether immediate action is imperative. This is the correct meaning of the express proviso that each $^{68}$ State judges for itself whether action in self-defence is necessary. But this does not mean that the State thus acting is the ultimate judge of the propriety and of the legality of its conduct. It is answerable if it abuses its discretion, if it avails itself of the faculty of self-defence as an instrument of conquest and lawlessness, if it twists the natural right of self-defence into a weapon of predatory aggrandizement and lust. The ultimate decision of the lawfulness of action in self-defence does not lie with the State concerned. For this reason the right of self-defence, whether expressly reserved or implied, does not impair the nature of a treaty as creating legal obligations. Under the Covenant of the League Japan was entitled to decide,

\footnotetext{
${ }^{68} \mathrm{Ibid}$.
} 
in the first instance, whether events in Manchuria justified resort to force in self-defence. But it was left to an impartial body of enquiry to find, as it did find, that there was in fact no justification for action in self-defence. To mention a more recent example, Article 51 of the Charter of the United Nations lays down that nothing in the Charter shall impair the inherent right of individual or collective self-defence in case of an armed attack. But it expressly leaves to the Security Council the power of ultimate action and determination. It is to be hoped that the judgment of this Tribunal will discourage, with appropriate finality, any future reliance on the argument that because a treaty reserves for the signatories the right of action in self-defence it becomes, for that reason, incapable of imposing upon them any effective legal obligation. ${ }^{69}$

[Note for Attorney-General: German counsels have not so far advanced the argument that this was not a war of aggression and that it was merely a war of self-defence. I am therefore not dealing, for the time being, with the question of the meaning and definition of aggression. H.L.]

I come now, my Lord, to that part of the case for the defendants in the matter of crimes against the peace which we anticipated at the opening of this trial, but which, in the circumstances, we expected would be put with more moderation. It has been strongly urged on behalf of the defendants that the very notion of criminal responsibility is incompatible with the basic assumption of international law, namely, with the sovereignty of States. A State, in the submission of Professor Jahrreiss, can commit an offence against international law; it cannot be made criminally responsible and punishable. To do that would mean to deny the sovereignty of States as what he called co-ordinated units of international society and to run counter to the established European conception of the State as the super-person.

My Lord, it is pathetic to see the accused who in their capacity as the German Government overran most of the States of Europe, who trampled brutally upon their sovereign independence, and who, with boastful and swaggering cynicism, made their sovereignty subservient to the new conception of the "Grossraumsordnung"-it is pathetic to see these defendants appealing to the mystic virtues of the sanctity of State sovereignty. It is equally pathetic to see them invoking orthodox international law to protect the defeated German State and its rulers from just punishment at the hands of the victorious Powers. Orthodox international law offers them no hope. ${ }^{70}$ It sets no limit to the legal power of the victor. The victor makes international law as between him-

\footnotetext{
${ }^{69} \mathrm{Ibid}$., at 56.

${ }^{70} \mathrm{Ibid}$.
} 
self and the vanquished. There are few propositions so elementary in accepted international law as this simple statement of the legal position. Even if there were a clear rule of international law excluding expressly the punishment of sovereign States-and we deny emphatically that there exists any such rule-it would be open to the victors, as a matter of law, to change that rule. It would have been easy for the Four Powers to make a treaty with a German Government expressing its concurrence in the provisions of the Charter-as they did in the analogous case at the end of the First World War. The full legal validity of that treaty would have been unimpaired by the fact that it was made under duress-although we can imagine a German Government which would very willingly endorse a treaty of this nature.

Of course, my Lord, in a sense these proceedings are not concerned primarily with punishing the German State. They are concerned with the punishment of individuals. ${ }^{71}$ On the other hand, the Four Powers have indicted the accused for acts which they committed as organs of the German State. For that reason we do not feel at liberty to ignore altogether the general question of criminal responsibility of States under international law. We submit, my Lord, that there is no substance at all in the view that by its very nature international law rules out any criminal responsibility for States for the reason that because of their sovereignty States cannot be coerced. ${ }^{72}$ As I pointed out in the opening speech for the prosecution, international practice in no way supports the view that the responsibility of States is limited to contractual liability. It is not easy to see why the sovereign will of States should be subject to responsibility in contract and tort, but not with regard to crimes. Many theories have been made to rest upon the broad shoulders of sovereignty, but these theories have not always been accurate. In the course of the work of the Permanent Court of International Justice it became a stock argument to rely on State sovereignty in support of the view that, as States are sovereign, treaty obligations entered into by them ought to be interpreted restrictively. The Court consistently discouraged that view. In its very first Judgment-a judgment given against Germany in The Wimbledon case ${ }^{73}$-it rejected the plea of sovereignty as a reason for restrictive interpretations of obligations in treaties. The Court declined to see in the conclusion of a treaty, by which a State undertakes to observe a definite line of conduct, an abandonment of its sovereignty. The Court reminded Germany that the very right to enter into

\footnotetext{
${ }^{71}$ Ibid.

${ }^{72} \mathrm{Ibid}$.

${ }^{73}$ SS Wimbledon (UK, France, Italy and Japan v Germany; Poland intervening), PCIJ Series A, No. 1 (1923).
} 
international engagements is an attribute of State sovereignty. The view that as States are sovereign they cannot be coerced has been abandoned long ago. The Covenant of the League of Nations made provision, in Article 16, for sanctions against sovereign States-sanctions being only another name for coercion, probably coercion of a punitive character. The Charter of the United Nations has followed suit-much more decisively. ${ }^{74}$ It is apparently not contrary to the dignity and the sanctity of the sovereign State that, when defeated, it can be subjected, with perfect legal propriety, to the ruthless and unfettered will of the victor, but, it is being suggested, it is contrary to its sovereignty if its criminal conduct is made subject to judicial proceedings. It is true that in the past, because of the absence of a competent compulsory jurisdiction, there is no judicial precedent for States being arraigned before a criminal tribunal. But to deny criminal responsibility for that reason is to suggest that there is equally no contractual responsibility seeing that, apart from treaty, there is no compulsory jurisdiction of international tribunals to adjudicate in matters of contract. The only innovation which the Charter has introduced has been to provide machinery which has been long overdue. ${ }^{75}$ On wider grounds the human mind revolts against the notion that the State whose potentialities for mischief are immeasurable should be exempt from criminal responsibility and that there should be no remedy, other than compensation, for the suffering inflicted by the author of aggression. Admittedly, there are compelling reasons for mitigating the rigours of the collective responsibility of the State in such a way as to prevent, so far as possible, the innocent from suffering for the guilty. It is for this very reason that we have indicted these defendants individually. But even this fails to satisfy counsel for the defendants. After having argued with learning that the State cannot be criminally responsible, they proceed to argue, with even greater learning, that individual persons acting on behalf of the State are not liable. Who then is liable? Who bears responsibility for these oceans of blood and for these calamities of suffering inflicted upon mankind? No one? Is there no limit to these attempts to reduce international law to an absurdity? However, enough has been said-assuming that it was necessary to say it at all in spite of the clear provision of the Charter-to show that there is no foundation for the complaint of the defendants that the Charter is a piece of post facto legislation either in declaring wars of aggression to be a criminal act or in assuming that the sovereign State is a proper subject of criminal responsibility. ${ }^{76}$

\footnotetext{
${ }^{74}$ Closing Speeches of the Chief Prosecutors, supra note 3, at 57.

${ }^{75}$ Ibid.

${ }^{76} \mathrm{Ibid}$.
} 
I come now to the third part of the Indictment, namely, the crimes against humanity-a charge which, like that of crimes against the peace, has caused the defendants and their protagonists to raise the strident complaint of novelty and retroactivity. That complaint, as we shall try to show, is unfounded. In the meantime it must be stated clearly that to a very large extent, so far as the fate of most of the defendants is concerned, the charge of crimes against humanity is almost theoretical. If the object of this trial were merely to bring just retribution upon the persons of these defendants we would have conveniently omitted all references to crimes against humanity. I will therefore ask your indulgence, my Lord, for stating as briefly as possible why we have nevertheless attached the very greatest importance to including the charge of crimes against humanity as part of the Indictment in this historic trial.

What are the crimes against humanity in the sense of the Indictment? In the first instance, to put it negatively, war crimes are not, in law, crimes against humanity. The object of the charge of crimes against humanity was to cover such acts as would not come under the clear legal category of war crimes. With regard to the latter the Tribunal possesses in any case an ample and undisputed jurisdiction. Crimes committed by Germany during the war in relation to belligerents and their nationals, whether committed in or outside Germany are war crimes-even though, of course, in the realm of conscience and morality they are also crimes against humanity. Similarly, crimes committed by Germany against German nationals in occupied territory are war crimes inasmuch as they constitute crimes against the civilian population in occupied territory. What then are crimes against humanity in the sense of the Indictment? They are clearly and exhaustively enumerated in Article 6 of the Charter, and perhaps it will be proper for me, with the permission of the Tribunal, to read that paragraph aloud: They are "murder, extermination, enslavement, deportation, and other inhuman acts committed against any civilian population before or during the war, or persecutions on political, racial, or religious grounds in execution of or in connection with any crime within the jurisdiction of the Tribunal, whether or not in violation of the domestic law of the country concerned." They are acts which the general principles of law, of criminal law-and not merely morality and decency-stigmatize as crimes. They are acts which the courts in any civilized country would treat as criminal but for the fact that they have been ordered by the State or by persons acting on behalf of the State. Now according to the Charter-and this is admittedly and undoubtedly an innovation-these acts of the defendants ordered or done by them in their capacity as the rulers and organs of the German State are to be treated as crimes 
irrespective of whether they were in accordance with the law of the German State as created and ruled by them. Acts of murder and of physical and spiritual persecution, even if done in accordance with the law of the State, are to be treated as crimes.

We do not deny the tremendous significance of the political and jurisprudential doctrine implied in that charge. It means not only that the will of the Nazi State as formed and governed by these defendants is not by the mere fact that it was the will of the State necessarily entitled to be regarded as law and as an absolute justification of acts committed in pursuance thereof. It means not only that the German Nazi State is not considered by the civilized world to have been a State under the rule of law. For this must henceforth be regarded as a doctrine of indisputably general application. The Charter affirms the principle that with regard to the fundamental rights of man there exists a higher forum than the positive law of any single State. As a rule international law recognizes that it is for the State to decide how it shall treat its nationals; this, in the current phrase, is a matter which is exclusively within the domestic jurisdiction of the State. The Covenant of the League of Nations and the Charter of the United Nations recognize that right. But at the same time international law claims that there is a limit to the omnipotence of the State, and the individual human being, the ultimate unit of all law, is entitled to the protection of the society of nations when the State tramples upon his rights in a manner which shocks and outrages the conscience of mankind. That principle was expressed more than three hundred years ago by Grotius, the founder of modern international law who described as just a war undertaken for the purpose of defending the subjects of a foreign State from injuries inflicted by their ruler. $\mathrm{He}$ affirmed, with reference to atrocities committed by tyrants against their subjects, that intervention is justified for "the right of human social connection is not cut off in such a case". ${ }^{17}$ It was given expression at the end of the last century by John Westlake, the most distinguished of British international lawyers, when he insisted that "it is idle to argue in such cases that the duty of neighbouring ${ }^{78}$ peoples is to look on quietly." "Laws", he said, "are made for men and not creatures of the imagination, and they must not create or tolerate for them situations which are beyond endurance." 79 The same principle of humanitarian intervention was acted upon by the European Powers to protect the Christian subjects of Turkey against cruel persecution. ${ }^{80}$ It is true that there have been occasions

\footnotetext{
${ }^{77}$ W. Whewell, Grotius on the Rights of War and Peace: an abridged translation (CUP, 1853), at 288.

${ }^{78}$ Closing Speeches of the Chief Prosecutors, supra note 3, at 63.

${ }^{79} \mathrm{~J}$. Westlake, International Law: Peace (CUP, 1910), at 320.

${ }^{80}$ Closing Speeches of the Chief Prosecutors, supra note 3, at 64.
} 
calling with extreme urgency for such humanitarian intervention and in which international society remained passive. This is what happened in relation to the abominations of the National-Socialist State in the years 1933-1939. The reason for that inaction was not that these outrages did not provoke the sustained wrath of humanity, but because of what were deemed to be the higher considerations of international peace. Thus the Charter of the Tribunal signifies an affirmation of an established and beneficent, though occasionally dormant, principle. ${ }^{81}$ Even in this respect it is not purely retroactive. International society may as yet lack means to enforce, by ordinary and effective processes, the respect of the inalienable rights of man. The Charter of the United Nations has inaugurated a further significant step in that direction. The Charter of this Tribunal gives warning to dictators and gangsters masquerading as a State that if they debase the sanctity of man by savage acts of persecution they do so at their own risk and peril. ${ }^{82}$ So far as these defendants are concerned this part of the Indictment is, in a sense, merely symbolic. Their conviction on this count cannot add to their punishment. For they stand accused and, we assert, convicted by overwhelming evidence of war crimes proper. Compared with the horror of war crimes, their crimes against their nationals, in their own country-for these are the crimes against humanity-cruel and outrageous as they were, are inconsiderable. Yet we ask the Tribunal to find that these defendants, in varying degrees and each within his own sphere, ranging from active evil-doing to active association with evil, are guilty of crimes against humanity which they committed by a vile assault on the dignity of men of their own race and of other races; by the persecution, humiliation and murder, without pity or compassion, of hundreds of thousands of their own nationals; by contemptuous disregard of the sanctity of man; by brutally invading the innermost recesses of the human mind and of man's relation to God; and by utterly depraving, in their own country, the very institution of the State which they set themselves to glorify.

I will now pass on, my Lord, to a survey of the particulars of the Indictment in relation to the various defendants.

\section{Closing Speech-Part III}

I have surveyed the acts with which the individual defendants and groups of defendants are charged as being war crimes, crimes against the peace, and crimes against humanity. It remains for me now to deal with two matters. The

\footnotetext{
${ }^{81}$ Ibid.

${ }^{82}$ Ibid.
} 
first is to attempt to reply to the two principal objections which the defence has put forward, as a matter of law, to the propriety of the Indictment. The first of these objections relies on an alleged rule of international law according to which persons acting as organs of a sovereign State-that is to say, performing an Act of State-are not personally accountable to other States and that the only available legal remedy is against the State. The second objection is based on the doctrine of superior orders. My second and final task will be to try to answer some of the doubts which have been raised, as a matter of international justice and jurisprudence, with regard to the proceedings before this Tribunal as a whole.

My Lord, with regard to the doctrine of Act of State and of the plea of superior orders we could, of course, cut short the argument by pointing to the clear letter of the Charter. The Charter rejects the doctrine of Act of State. It says expressly that there shall be individual responsibility of the defendants in respect of the crimes with which they are charged. And, subject to the proviso of extenuating circumstances, it lays down that the plea of superior orders shall be no defence. However, for reasons which I have already stated, we deem it our duty to meet the defence on their own ground and to examine whether, as they maintain, the Charter is in these respects yet another example of ex post facto legislation inconsistent with accepted principles of international law. We shall submit to you, my Lord, that as the law stands the defendants are not entitled to the moral and political advantages of the claim that in these matters the Charter is retroactive. It is not. It is in accordance with international law and with general principles of criminal law as recognized by civilized States.

And first as to the plea of Act of State. The argument of the defence is that according to international law individuals acting as organs of a State are subject to the jurisdiction of that State only. If a foreign State were to assume jurisdiction over them it would, in effect, be assuming jurisdiction over their State-an act which would clearly be contrary to the principles of State sovereignty, of State equality and of jurisdictional immunity of States in general. We will examine these submissions in some detail. But let it be explained at the outset that whatever be the rule of international law on this subject generally, there is no doubt that with regard to war crimes proper the belligerent has full and uncontested jurisdiction over the nationals of the enemy State. It is of no consequence that in committing a war crime the accused acts as the organ or on behalf of the State. (I am not dealing here, my Lord, with any question of superior orders-a subject to which I will come later on. I am concerned with war crimes committed on the responsibility of the accused.) It is of the 
very essence of the branch of international law relating to war crimes that it is concerned primarily with acts done on behalf of the State-although, of course, it covers also private acts of lawlessness such as plunder and other crimes of lust and greed. To give an example, if it is proved that the German Naval High Command issued orders which aimed at or had the effect of preventing the rescue of shipwrecked members of crews, this would be a war crime and it would be entirely irrelevant to say that the accused acted for the German State. Counsel for the defendants have not challenged this view of the legal position. Their appeal to the doctrine of Act of State was directed, it appears, only to the charge of crimes against the peace. As in our submission ordinary war crimes are the main burden of the Indictment it would be natural if we declined to enter into a controversy which is in any case of a theoretical character with regard to all three parts of the Indictment seeing that the Charter prescribes individual responsibility with regard to all of them. Yet we do not propose to allow the defence and its protagonists to reap the advantage, which they may put to a variety of uses, of having invoked what they assert to be an established principle which the prosecution did not even attempt to challenge. What authority is there for the proposition that because of the rule, recognized in international law, of jurisdictional immunities of foreign States, a State is bound invariably to refrain from exercising its own jurisdictional rights with regard to unlawful acts committed against it or against the laws of humanity? Such authority is said to be grounded in a long series of judicial decisions in which courts have affirmed that one State has no jurisdiction over another sovereign State, over its head of State, over its property, including its public ships, and over its diplomatic representatives. The reason underlying these decisions is said to be that to assume jurisdiction over a State and its representatives would mean to deny its independence. These decisions go back to the important judgment of Chief Justice Marshall in the case of Schooner Exchange v. McFaddon in which that great Judge ruled that American courts had no jurisdiction over a public ship of the French State. ${ }^{83}$ But there is every reason to assert that he would have been astonished to find his judgment relied upon in support of the claim that, apart from the drastic remedies of war and reprisals, a State is impotent to protect itself against unlawful acts undertaken on behalf of a foreign State. What Chief Justice Marshall said was that "all sovereigns have consented to a relaxation, in practice, in cases under certain peculiar circumstances, of that absolute and complete jurisdiction within their respective territories which sovereignty confers." He added: "... all exemptions from territorial jurisdiction

837 Cranch 116, 11 U.S. 116 (1812) 
must be derived from the consent of the sovereign of the territory. ... [T] his consent may be implied or expressed; and ... when implied, its extent must be regulated by the nature of the case, and the views under which the parties requiring and conceding it must be supposed to act." And he added further that "without doubt, the sovereign of the place is capable of destroying that implication." And these guarded and qualified propositions, in relation to a matter of limited compass, have been magnified to embrace the impunity of acts directly injurious to the territorial sovereign and the general immunity of persons acting on behalf of the State! The decisions of English courts have invariably placed that rule of jurisdictional immunity of foreign States and their agents on the precepts of comity of nations and of peaceful and smooth international intercourse. They are no authority whatsoever for the sweeping deductions which have been made from the principle of immunity of foreign States. ${ }^{84}$ Thus while interpreting most generously the rules as to diplomatic immunity, they declined to base it on any sacrosanctity of foreign sovereignty. They based them on requirements of smooth diplomatic intercourse: ne impediatur legatio. Continental countries have declined to treat jurisdictional immunity as absolute. They have drawn a distinction between public acts and acts of a private law nature. And there are indications that English and American courts may adopt that distinction with regard to treatment of public vessels.

While judicial practice thus affords no support whatsoever for any rigid and far-fetched interpretation of the principle of jurisdictional immunity of States in the sense contended for by the defendants, considerations of common sense make such interpretation appear to be grotesque. Suppose a State were to send a body of persons into the territory of another State with instructions to rob and murder, would these persons be immune from ordinary criminal processes because, in the fulfilment of the criminal design, they were acting as organs of another sovereign State? Suppose the individuals who ordered the predatory expedition were to fall into the hands of the attacked State, would they be entitled to plead an Act of State ${ }^{85}$ The analogy with the predatory aggressions of the Nazi State-that magnum latrocinium of modern times-is close. My Lord, we submit that the principle of the immunity in the international sphere of persons committing criminal acts on behalf of their State is unsupported either by authority or by common sense and is a figment of half-baked learning.

I come now to the second complaint concerning the express provision of

\footnotetext{
${ }^{84}$ Closing Speeches of the Chief Prosecutors, supra note 3, at 58.

${ }^{85} \mathrm{Ibid}$.
} 
the Charter which lays down the principle of individual responsibility of the defendants. It has been asserted that the Charter is in this respect contrary to a basic principle of international law according to which States only, and not individuals, are subjects of international law, that is to say, subjects of international rights and duties. My Lord, there is no such basic principle of international law. There are numerous examples of duties being imposed by international law directly upon individuals. In the case of piracy and breach of blockade individuals are directly subject to international law. War crimes, as distinguished from crimes against the peace, have always been generally recognized as being in that category. So are spies. In the recent case Ex parte Quirin, decided by the Supreme Court of the United States, that great tribunal fully affirmed the same view. ${ }^{86}$ In England and in the United States courts have invariably acted on the view that universally recognized customary rules of the law of nations are part of the law of the land and directly binding upon the subject and the citizen. The position is essentially the same in most countries. In Germany itself Article 4 of the Weimar Constitution laid down that generally recognized rules of international law must be regarded as an integral part of German Federal Law. What else does this all mean but that rules of international law are directly binding upon the individual? Shall we suspend the operation of that principle for the mere reason that we are confronted with the gravest offence of all, with offences against the peace of nations and humanity? In no other sphere is it more necessary to affirm the principle that the rights and duties of States are the rights and duties of men and that unless they are the rights and duties of individual persons they are the rights and duties of no one. In no other sphere is it more imperative to disdain the artificial distinction between the corporate entity of the State and those who act on its behalf. The Charter of the Tribunal has ignored that distinction. In doing so it has confirmed and clarified a legal doctrine of transcending beneficence and authority.

It will not be necessary to take up a great deal of the time of the Tribunal in considering the question of the plea of superior orders-although this is a defence which has loomed most prominently in the speeches for the defence. The orders of the Führer were the supreme law operating with irresistible physical compulsion and spelling the doom of any person who failed to comply with them. My Lord, if the matter before this Tribunal were not one transcending and forbidding the natural impulses of pity, there would be commiseration with those once proud leaders of the nation now in abject

${ }^{86} 317$ U.S. 1, 87 L. Ed. 3 (1942). 
self-debasement screening themselves behind the orders of a man whom they now denounce as the author of the greatest murders in history. There is no difficulty about the plea of superior orders in this Court, my Lord. This is so not because the Charter expressly rules out such considerations. It is because of more compelling considerations. As is well-known, the question of the relevance of the plea of superior orders is one of great complexity in constitutional law. It is an established principle in most countries, including Germany, that obedience to manifestly illegal orders does not relieve the author of the act of legal responsibility. In some countries, like Great Britain and the United States, it is not even necessary that the order should be patently illegal. On the other hand, it is recognized that military law prescribes obedience to orders and sometimes immediate and drastic sanctions for disobedience. In practice, common-sense and the exercise of the executive prerogative of pardon affect a reconciliation of two apparently conflicting legal principles. However, in the case before the Tribunal all these difficulties and complexities hardly arise. The Tribunal is not confronted with humble soldiers and officers obeying unlawful and criminal orders, in isolated cases of killing and murder, on pain of themselves being exposed to proceedings before a court martial or immediate death. The Tribunal is confronted with leaders, with friends, co-operators, associates and advisers of the person to whom they now, with nauseating unanimity, attribute the authorship of the criminal acts which they executed or helped to execute. Can it be believed that their opposition to these orders would have exposed them to mortal danger to their persons? Or is it not pre-eminently reasonable to assume that determined resistance on their part would have resulted, possibly after an initial outburst of fury in the person of the Führer, in a modification or abandonment of the criminal command? Defendant Jodl, and other gallant defendants in the dock, have said that disobedience to the orders of the Führer would have resulted in their immediate dismissal and arrest. It is highly improbable that that would have been the result-especially if the Führer knew that this would also have been the attitude of those called in to replace them. But even if we assume that dismissal and arrest would have followed-even if we assume that, is it possible, my Lord, to stifle a feeling of incredulous disgust at the brazen clumsiness of the explanation? What are the dangers conjured up by the accused in comparison with the enormity of the crimes which they helped to execute? Even if these accused could produce the fantastic proof that their own death would have followed the refusal to associate themselves with the criminal policies and orders of the Führer, we submit, with the utmost urgency, as an absolutely irresistible proposition of law, that such proof would be utterly futile and irrelevant. It may be permissible to attempt 
to save one's own life by killing another-though this is certainly not the law of my own country-but it is without a shadow of doubt criminal to try to save one's life by bringing about or helping to bring about the deaths of thousands and millions. We accordingly submit to the Tribunal, as a matter of law, that, even if the Charter had been silent on the subject, these defendants would be clearly precluded from invoking the justification of superior orders. It follows from the considerations we have adduced that they are not entitled to rely on the provision of the Charter which permits the plea of superior orders as an extenuating factor in mitigation of the punishment decreed by the Tribunal.

The accused may say, as some of them seem to have said in the course of these proceedings, that in obeying unlawful orders because of jeopardy to their lives, they had in mind not their own personal well-being but the subsection of the German State to the service of which they were dedicated. We do not wish to probe into the motives which made their lives appear to them so precious. But if there is a semblance of substance in that, then it does away with the plea of superior orders conceived as irresistible physical compulsion. The right of a nation to commit crimes-and, in this case, what crimes!-for promoting its ends is not a legitimate factor in the plea of order.

For these reasons we deny that Article 8 of the Charter which authorizes the Tribunal to mitigate punishment on account of orders of superiors if justice so requires is relevant to the case of the present defendants. That Article may be applicable to subordinate members of the groups or organizations which the Tribunal may declare to be criminal in accordance with Article 9. With regard to such persons the Charter, far from being in the nature of retroactive legislation, confirms and interprets generously the existing rule of international law on the subject. The overwhelming majority of legal opinion declines to accept the plea of superior orders inasmuch as it reduces the laws of war to an absurdity by shifting responsibility from one superior to another until it reaches the Chief of State who is often claimed not to be subject to any liability whatsoever. The members of criminal organizations may attempt to rely on the British and American military manuals which is mistaken reliance on a mistaken view of a single writer, for a time seemed to regard superior orders as an unqualified justification. That view was subsequently abandoned. In any case these provisions of military manuals, being out of keeping to the general principles of constitutional and criminal law of these countries cannot be regarded as an authoritative and binding expression of their views on the subject. They were in the nature of information, now shown to be incorrect, transmitted to military authorities. On the other hand, the Charter can be properly construed 
as authorizing the Tribunal to prescribe for the guidance of those charged with the prosecution of members of criminal groups and organizations, in what circumstances justice may require the mitigation of punishment on account of superior orders. Actual and continuous participation in the execution of orders which are both patently illegal and inhuman necessarily rules out any mitigation of punishment. At the same time the Tribunal may deem it proper to lay down that isolated assistance in carrying out orders which are not manifestly criminal, in circumstances excluding any reasonable possibility on the part of the accused, to disobey or to attempt to modify the order, is a factor which be adduced in mitigation of punishment. This would apply, in particular in cases in which owing to the uncertainty as to the actual rules of international law or to an asserted exercise of the right of reprisals within the limits of international law, the criminality of the act was not manifestly obvious.

These submissions relating to Article 7 of the Charter in the matter of responsibility of persons in official position - the Act of State doctrine-and to Article 8 in the matter of superior orders conclude the purely legal part of this final address for the Prosecution on behalf of His Majesty's Government. We have been concerned, my Lord, to show that with regard to neither of them is there sufficient justification for the complaint that the Charter, far from merely applying existing law, constitutes an innovation and a departure from basic principles of international law. We have attached throughout the very greatest importance to dispelling the assiduously fostered impression of retro-activity. We attempted to do the same with regard to the parts of the Indictment bearing upon crimes against the peace and crimes against humanity. There is, of course, no question of any post factum legislation in the matter of the principal part of the Indictment, namely, war crimes proper. Now, my Lord, the reasons for which the charge of retro-activity has been put forward and re-iterated in a variety of ways before this Tribunal and outside this Court room is transparent. It is, in law, a challenge to the jurisdiction of the Tribunal. To that extent the Tribunal is bound to ignore it. But it is also a challenge to the moral authority of the Charter, of the Court and of its judgment. It is an appeal to the outside world.

We would have been failing in our wider duty if we had not attempted to show that that shrill complaint has no foundation whatsoever in relation to the principal count of the Indictment; that it is, in substance, unfounded with regard to the others; and that it has no support in international law with regard to Articles 7 and 8 of the Charter bearing on official acts and superior orders. The defence has exhibited some ingenuity in cultivating this particular 
argument so tenaciously and so solemnly. The civilized world is sensitive, and justly sensitive, on this point. The principle that no person shall be punished for an act which was not a crime at the time when it was committed must now be regarded as a general principle of criminal law recognized by civilized States. It is also an elementary principle of justice. To deny it is to sanction legislative tyranny in its most objectionable form. Its prohibition goes back to the weighty declaration of the rights of man in the French Declaration of $1789^{87}$ and of the American Constitution. ${ }^{88}$ Most modern constitutions expressly forbid the retroactive [application] of criminal law.

It would have been easy for us, as it would have been perfectly justifiable, to insist that as the principle nulla poena sine lege is in itself primarily a principle of justice it must be made to yield to situations in which justice requires that it be disregarded. We have not chosen to follow this line of reasoning. It would have been open to us to argue that if the Charter be retroactive it merely applies the innovation introduced by the Nazi régime which permitted retroactive punishment according to what it describes as "the people's sense of justice". The Tribunal will have noted the subtle explanation of the counsel for the defendant Goering according to which that latitude of courts was to be exercised within the Courts of National-Socialist ideology-what a safeguard and what an ideology! The Nazi régime expressly repudiated Article 2 of the German Criminal Code which forbade punishment unless it is prescribed by a statute enacted before the act was committed. We might argue that it is just to apply to the accused a rule which they themselves enacted. We might urge that it is unjust that these accused should be permitted to invoke a rule which they themselves rejected and ridiculed. But we should be sorry to descend to their level of jurisprudence. We do not wish to see the formal rules of estoppel applied to fundamental principles of law and justice. Instead we have urged that there is no question of retroactivity in Article 6 of the Charter which lays down the jurisdiction of the Tribunal. War crimes are war crimes and have always been so; crimes against the peace were recognized to be such by virtue of solemn treaties and of customary international law which has grown around them; crimes against humanity and crimes by virtue of general principles of law-of law, and not only of justice-which these defendants outraged and defiled. We beg all-except those who are intent upon misleading or being

\footnotetext{
${ }^{87} 1789$ Declaration of the Rights of Man and [of] the Citizen (Déclaration des droits de l'homme et du citoyen), available at <http://avalon.law.yale.edu/18th_century/rightsof.asp> [last accessed 12 May 2012].

${ }^{88} 1787$ Constitution of the United States, available at <http://www.house.gov/house/Cons titution/Constitution.html> [last accessed 12 May 2012].
} 
misled-to ponder most seriously before they lend countenance to the charge that the Charter created, to the prejudice of the defendants, a series of crimes which were not crimes before 1939 and 1945.

Undoubtedly the Charter introduced one innovation: It created an instrument for trying these crimes. That instrument has always existed with regard to war crimes though in a form less perfect and less favourable to the defendants than in the present case; it was absent in the matter of crimes against the peace and of crimes against humanity. For that innovation we take full responsibility before the [Court] of history. To that extent the Tribunal is an improvisation. But this is not in itself a defect or a legitimate cause of criticism. Prior to the establishment of the Permanent Court of International Justice all international tribunals were improvised bodies set up ad hoc by special agreements. All civilized communities improvise remedies and institutions in time of emergency. There has never been a graver emergency in the administration of International justice-confronted as we are with the greatest crimes ever committed by a human agency. It would shock the conscience of mankind as it would sap the very foundations of international order and morality if we were to abstain from meeting that emergency because of any fear of procedural innovation. It is of no consequence that the rules of procedure and of evidence have been improvised so long as the Tribunal which administers them succeeds in imbuing them with these qualities of wisdom, of fairness and of impartiality which are the life of law. Can any unprejudiced person entertain doubts as to whether this Tribunal has succeeded in achieving that result?

The way in which the Tribunal gave meaning and vitality to the few and general rules of procedure and evidence laid down in the Charter ought to dispose of the suggestion that this is [a] trial of revenge at the instance of the victor. But there are even more compelling reasons which make any such suggestion improper and, in a very real sense, blasphemous. Is this a trial the main object of which is to take the lives of these defendants? What are the lives of these twenty defendants put against the lives, the agony, the torture, the suffering, and the humiliation of the millions which they sent to their doom? It is only by an ignominious and malevolent corruption of language that one can speak of revenge in a case such as this. Revenge implies some proportion between punishment and crime. There cannot be such proportion in this case. It is probable that those who were not present throughout these proceedings or who have not read the full record, may find it difficult to realize the infinite chasm between the horror of the crimes here recounted and the possibilities of any physical retribution upon the persons of these defendants. Torture is 
but a word and human imagination finds it difficult to grasp what is implied in it unless it is confronted with a picture as terrifying and as authentic as those who were here rendered by Dr. Blaha and by many others. The death of one innocent person and of many innocent persons inspires compassion and anger. But the death of innocent millions almost tends to become a mere political concept to persons who, unlike those present in this Court, have not come to agonizing grip with the evidence of that most catastrophic event in human history. To those who have been present here and who will read the evidence before presuming to pronounce judgment, the idea that this trial is a trial of revenge will be as fantastic as the notion that any imaginable retribution upon the defendant could, in any true sense of the word, avenge the deaths of the millions murdered by them or at their behest or with their assistance, connivance, and encouragement.

Yet if this is not a trial of revenge what is its purpose? This trial, my Lord, is intended to serve three objects. In the first instance, its purpose is to mete out justice according to law and to punish the guilty. Of such punishment retribution is one, but only one element. But clearly, the ends of punishment reach beyond that elementary purpose. The fate of these accused will be a deterrent not only to any intending transgression of the laws of war. It will be a warning to potential authors of wars of aggression. And, it will serve as a most explicit reminder that the domain of exclusive domestic jurisdiction ends where crimes against humanity begin. Such warning may or may not be heeded in the future. But we would be guilty of a dereliction of duty if we omitted to issue it at this juncture of history or if we were to flout the outraged conscience of mankind by failing to vindicate the fundamental law of the world.

Secondly, these prolonged judicial proceedings and the judgment of the Tribunal will provide a most authoritative, thorough and impartial ascertainment of the sombre facts of these crimes and these tragedies. What many have hitherto appeared to the incredulous mind as a morbid and studiously exaggerated figment of propaganda has here been revealed in the stark reality of an historical event not challenged even by the accused. Would private research have succeeded in assembling that mass of evidence and documents, carefully authenticated under stringent judicial safeguards, subjected to conscientious scrutiny as to its admissibility and relevance, and exposed to the oral procedure, in full Court, of examination, verification, and explanation? There cannot now be a dispute as to the facts or as to the judgment of the Tribunal as based on them. This is one-although certainly not the most important reasons for dismissing the frivolous advice that the guilt of these defendants is so obvious that they 
ought to have been done away with, out of hand by executive decision, without it being necessary to stage a costly and prolonged trial. It is possible that their guilt may have been obvious in any event-but there is a difference, which is of the very essence of the jurisprudence of civilized nations, and which counts heavily in the balance of history between guilt as proved by popular consent and guilt as ascertained by ordinary and exhaustive judicial processes. I need not elaborate the point that we consider [the] executions of persons by political decision and without the safeguards of judicial trial to be utterly contrary to those abiding tenets of the sanctity of human personality with the contemptuous disregard of which we charge these defendants.

Finally, one of the most important aims of this trial is to declare and to clarify such rules and principles of the law of nations as are relevant to the Indictment and to the interpretation of the provisions of the Charter which bear upon it. The Tribunal is an international Court and the Charter is an international treaty. It will be interpreted not arbitrarily but by reference to international law, the rules and doctrines of which counsel for the defence have invoked. The Tribunal will decide on such contentions as that the changed conditions of modern warfare permit the belligerent to throw overboard fundamental principles of the law of war; or that the reservation of self-defence in treaties prohibiting resort to war deprives these treaties of any element of effective legal obligation; or that the individual responsibility of the defendants for acts committed by them is contrary to basic doctrines of the law of nations. The Tribunal will note incidentally that many of the defendants caused frequent researches to be made into various branches of international law and that the proved object of these researches was not to honour the law of nations but the resolve to break it with a minimum of risk and a maximum of plausibility. And the Tribunal will not be the occasional admission, as in the case of counsel for the defendant Goering, that as this was a war for the very existence of nations and as it was a war in which all values had changed "the defendant had the right feeling when he declared: After all there is no legality in the fight for life or death?"

These then, my Lord, are the objects of this trial. It is to[o] much to hope that the accused and their German defenders and protagonists will henceforth refrain from proclaiming that this was a trial of revenge. But the proceedings of this Tribunal have been a most compelling exhortation to all persons of good will not to fall prey to the facile assumption that this trial, being a trial before Court set up by the victors is a mere trial of revenge. These victors-the four signatories of the Charter and the nineteen States which adhere to it-represent 
the overwhelming majority of the population of the world. For this reason the moral and judicial standing of this Tribunal remains unshaken by the fact that it is composed only of the nationals of the victors. It is, in the nature of things, a tribunal as international as is practicable after a war in which practically the entire civilized world managed itself against the authors. No decisive accession of impartiality and detachment could be expected from the presence of a neutral national on this Tribunal. It is no disparagement of the few remaining neutral States to say that they would not and could not claim to embody that authority which the victors claim for themselves, namely, that in that struggle for their own survival their fate was identified with the very survival of the law of nations.

It will be objected in some quarters that this is a sanctimonious claim. History will judge. Neither is the significance of these proceedings in the least impaired by the fact that the victors have, so far, failed to make provision for the indictment of any war criminals of their own. We do not rule out that possibility. But we deny, with the utmost conviction, that matter is relevant to the moral and legal authority of these proceedings. If the victors were to indict any war criminals of their own they would be establishing a kind of symmetry in the administration of justice. But it would be a symmetry which would be purely formal, elusive, and deceptive. Because we proclaim - and, again, history will judge-that there is no legitimate comparison between any isolated war crimes committed by the armed forces of the United Nations and that gigantic accumulation of horrors of crimes against the peace, against the laws of war, and against the laws of humanity perpetrated by these defendants. It would have been unjust, it would have been indecent, it would have been unreasonable in the highest degree to allow the abysmal disparity between any war crimes of the forces of the United Nations and the great crime of these defendants to be blurred by any simultaneous or even parallel proceedings.

My Lords, I have now come to the close of these final submissions of the Prosecution on behalf of His Majesty's Government. This trial would have been shorter if the Charter had confined the proceedings to war crimes proper. Any such limitation of the scope of the trial would not have materially affected the fate of these defendants-apart from one or two exceptions. However, for reasons already stated, this was, in the view of the Four Powers, an absolutely imperative occasion for providing an international jurisdiction for giving effect to the rules of international law rendering criminal wars of aggression and the violation of the enduring laws of humanity. These final submissions of the Prosecution would have been shortened if we had been content merely to ask 
for the application of the mandatory provisions of the Charter. But we have deemed it our inescapable duty to present these clear articles of the Charter in the background of the law of nations as a living and growing body of principled doctrine. For this is a trial not only before this Tribunal, but also before the enlightened conscience of the entire civilized world.

The Charter does not prescribe the penalties to be imposed by the Tribunal, and it is not our intention to make submissions under this head. But we consider it pre-eminently proper, in this context, to submit to the Tribunal that in the light of the evidence produced in this Court these defendants, with the exception of a few, are guilty of murder-not only of that constructive murder which is synonymous with a war of aggression, but of murder-or a definite part in murder-in its direct, literal, common connotation. This, in its stark reality, is the gist of the evidence here produced. The Tribunal will lay down, in words commensurate with the tragic magnitude of the business before it, that murder does not cease to be such for the mere reason that its victims are numbered in millions or that it is committed on behalf of the State. They, the defendants, were the State. They, in their deeds, embodied the greatest perversion, known in the history of man, of the true meaning and function of the State. Even in the course of this trial the good of the German State remains for them the supreme test and final justification of conduct.

Neither have they seriously attempted to palliate the anger of the civilized world by a simple admission of guilt. Even the abject confessions, with a ring of sincerity about them have been no more than artful evasions. Witness, for instance defendant Frank confessing to a sense of deepest guilt because of the terrible words which he had uttered-as if it were his words that mattered and not the terrible deed which accompanied them. What might have become a redeeming claim to a vestige of humanity reveals itself as a crafty device of desperate men. He, like other defendants, have pleaded, to the very end, full ignorance of that vast organized and most intricate ramification of the foulest crimes that ever sullied the record of a nation.

These crimes transcend any conceivable measure of individual retribution. They have raised issues infinitely weightier than the fate of the defendants. These issues will, we hope, find a proper and solemn place in the judgment of the Tribunal in terms not only of stern justice and of legal principle but also of the loftier hopes of international society. Of these hopes the very Charter of this Tribunal is an auspicious augury. It has given formal sanction the principle that the duties of States are the duties of the human beings who compose them and who govern them. The duties enjoined and enacted by the law of 
nations are the duties of man. In a different sphere another Charter-that of the United Nations-has taken the first steps towards the enthronement of the rights of man-of fundamental human rights and freedoms - as an integral part of the constitution. We know now that that great outcome is due in no small measure to the revulsion against the assault which the State governed by these defendants had made upon the inalienable human rights. Thus a new epoch is opening in human government with the rights and duties of the individual in the very centre of the constitutional law of the world. But these new mansions of faith, progress and order will not be built on secure foundations until the impersonal sovereignty of the law has, through this Tribunal, pronounced judgment upon these authors of the greatest evils and the greatest crimes yet inflicted by human beings upon their fellow men. 